\title{
Bioactivity of Dietary Polyphenols: The Role in LDL-C Lowering
}

\author{
Peng Sun ${ }^{1}$, Liang Zhao ${ }^{2} \mathbb{D}$, Nanhai Zhang ${ }^{1} \mathbb{D}$, Jingxuan Zhou ${ }^{1}$, Liebing Zhang ${ }^{1}$, Wei Wu ${ }^{3}$, Baoping Ji ${ }^{1} \mathbb{D}$ \\ and Feng Zhou ${ }^{1, *(D)}$
}

Citation: Sun, P.; Zhao, L.; Zhang, N.; Zhou, J.; Zhang, L.; Wu, W.; Ji, B.; Zhou, F. Bioactivity of Dietary Polyphenols: The Role in LDL-C Lowering. Foods 2021, 10, 2666. https://doi.org/10.3390/ foods10112666

Received: 5 September 2021

Accepted: 31 October 2021

Published: 2 November 2021

Publisher's Note: MDPI stays neutral with regard to jurisdictional claims in published maps and institutional affiliations.

Copyright: (c) 2021 by the authors. Licensee MDPI, Basel, Switzerland. This article is an open access article distributed under the terms and conditions of the Creative Commons Attribution (CC BY) license (https:// creativecommons.org/licenses/by/ $4.0 /)$.
1 Beijing Key Laboratory of Functional Food from Plant Resources, College of Food Science and Nutritional Engineering, China Agricultural University, Beijing 100083, China; sunpeng666@cau.edu.cn (P.S.); nanhaizhang@cau.edu.cn (N.Z.); zjx888@cau.edu.cn (J.Z.); lbzhang@cau.edu.cn (L.Z.); jbp@cau.edu.cn (B.J.)

2 Beijing Advance Innovation Center for Food Nutrition and Human Health, Beijing Engineering and Technology Research Center of Food Additives, Beijing Technology and Business University, Beijing 100048, China; liangzhao@btbu.edu.cn

3 College of Engineering, China Agricultural University, Beijing 100083, China; wuweiyin@cau.edu.cn

* Correspondence: zf@cau.edu.cn; Tel.: +86-10-6273-7129

\begin{abstract}
Cardiovascular diseases are the leading causes of the death around the world. An elevation of the low-density lipoprotein cholesterol (LDL-C) level is one of the most important risk factors for cardiovascular diseases. To achieve optimal plasma LDL-C levels, clinal therapies were investigated which targeted different metabolism pathways. However, some therapies also caused various adverse effects. Thus, there is a need for new treatment options and/or combination therapies to inhibit the LDL-C level. Dietary polyphenols have received much attention in the prevention of cardiovascular diseases due to their potential LDL-C lowering effects. However, the effectiveness and potential mechanisms of polyphenols in lowering LDL-C is not comprehensively summarized. This review focused on dietary polyphenols that could reduce LDL-C and their mechanisms of action. This review also discussed the limitations and suggestions regarding previous studies.
\end{abstract}

Keywords: cardiovascular diseases; LDL-C; metabolism pathways; dietary polyphenols

\section{Introduction}

Cardiovascular diseases (CVDs) have now become the leading cause of morbidity and mortality worldwide [1]. Some studies indicate that atherosclerosis is the principal pathogenic mechanism of CVDs [2,3]. An elevation of the low-density lipoprotein (LDL) cholesterol level in plasma is one of the most important risk factors for atherosclerosis [4]. To achieve optimal plasma LDL-C levels, huge amounts of therapies were investigated and implemented which targeted different metabolism pathways. For example, statins, the first-line drugs for lowering LDL-C levels, could inhibit the expression and activity of hepatic 3-hydroxy-3-methylglutaryl coenzyme A reductase (HMGR) and upregulate the expression and activity of the LDL receptor (LDLR) [5]. In clinical practice, however, about $50 \%$ of statins-treated patients do not achieve a desirable LDL-C level [6]. Thus, there is a need for new treatment options and/or combination therapies to suppress the plasma LDL-C level.

Studies have found that the intake of fruits and processed foods could directly reduce the LDL-C level, both of which were associated with their bioactive components like polyphenols [7-9]. Polyphenols refer to a large group of compounds containing aromatic ring(s) with one or more hydroxyl functional groups [10]. Based on their chemical structure, dietary polyphenols are mainly classified into phenolic acids, flavonoids, lignans, stilbenes, and phenolic polymers [11]. Flavonoids can be further divided into six subgroups: flavonols, flavones, isoflavones, flavanones, anthocyanidins, and flavanols [12]. In recent years, dietary polyphenols have received much attention in diseases prevention, 
such as type 2 diabetes, osteoarthritis, obesity, hyperlipidemia, hyperuricemia, etc. [13-17]. Our laboratory studies indicated that polyphenols could decrease plasma LDL-C levels in animal trials [18-21]. However, the effectiveness and potential mechanisms of polyphenols in lowering LDL-C is not comprehensively summarized. Therefore, in this review, we will discuss the effects and modes of action of dietary polyphenols on lowering LDL-C.

\section{Metabolism Pathways for Lowering LDL-C}

To achieve optimal plasma LDL-C levels, different metabolism pathways need to be considered. Currently, the metabolism pathways include the production and elimination of plasma LDL-C, the absorption of intestinal cholesterol, the production of very low-density lipoprotein (VLDL), the transfer of cholesterol esters through cholesterol esters transfer protein (CETP), the endocytosis of LDL via LDLR, and the formation and enterohepatic circulation of bile acids. Further details are mentioned below.

\subsection{Intestinal Cholesterol Absorption}

There are two recognized sources of cholesterol in the body: biosynthesis and the intestinal absorption of dietary cholesterol [22,23]. Inhibiting cholesterol absorption had been shown to reduce the levels of cholesterol in the liver, thereby promoting the synthesis of LDLR (Section 2.4, below) and a subsequent reduction of plasma LDL-C levels [24]. Cholesterol absorption is a complex process which is regulated by a set of proteins: NPC1-like transporter 1 (NPC1L1), acyl-coenzyme A: cholesterol O-acyltransferase 2 (ACAT2), microsomal triglyceride transfer protein (MTP), and apolipoprotein B-48 (apoB48) (Figure 1) [25-27]. By contrast, some cholesterols are secreted back through adenosine triphosphate-binding cassette transporters G5 and G8 (ABCG5/8) [27]. Subsequently, the cholesterol is passed out from intestine [28].

\subsection{VLDL Assembly and Secretion}

VLDL mainly delivers cholesterol and triglyceride from the liver to the bloodstream [29]. After processing in the bloodstream, VLDL is further translated into intermediate density lipoprotein (IDL) and then LDL particles by lipoprotein lipase (LPL) and hepatic lipase (HL) $[30,31]$. Thus, impairing liver VLDL production may reduce the rate of LDL production and the LDL-C level $[32,33]$. The assembly of VLDL involves a stepwise lipidation of apolipoprotein B100 (apoB100) in the liver (Figure 2) [34]. The first step of VLDL assembly is lipidation of apoB100 by MTP to generate pre-VLDL in the rough endoplasmic reticulum [35]. Moreover, the phospholipid transfer protein (PLTP) is also implicated in VLDL assembly and secretion through the blockade of apoB100 destruction [36,37]. The second step is the fusion of pre-VLDL with triglyceride-rich lipid droplets in the lumen of the smooth endoplasmic reticulum [38]. The nascent VLDL further moves from the endoplasmic reticulum to the Golgi and then transports from the Golgi to the plasma membrane [39].

\subsection{CETP in LDL Metabolism}

Cholesterol esters transfer protein (CETP), a 476-residue hydrophobic glycoprotein, is synthesized mainly in the liver that engages the bidirectional transfer of cholesterol esters and triglycerides between lipoproteins [40]. The CETP promotes the transfer of cholesterol esters from high-density lipoprotein (HDL) to VLDL and LDL to exchange triglycerides (Figure 3). This produces triglycerides-enriched HDL and cholesterol-enriched LDL and VLDL are produced [41]. Inhibition of CETP activity can increase the concentration of HDL-C and lowers the concentration of LDL-C and VLDL-C in the plasma [42]. 


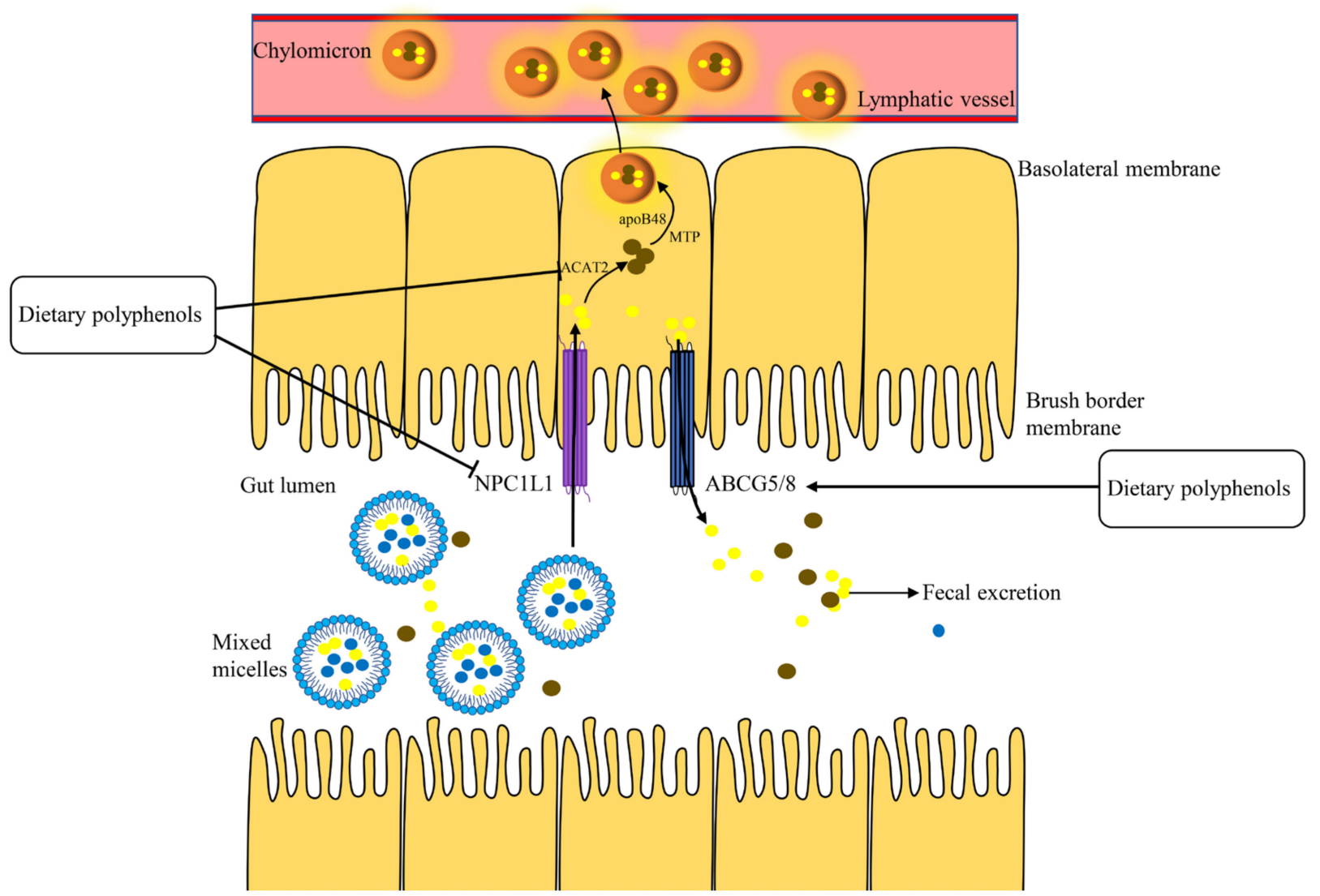

Figure 1. Intestinal cholesterol absorption. ACAT2, acyl-coenzyme A: cholesterol O-acyltransferase 2; MTP, microsomal triglyceride transfer protein; NPC1L1, NPC1-like transporter 1; ABCG5/8, adenosine triphosphate-binding cassette transporters G5 and G8.

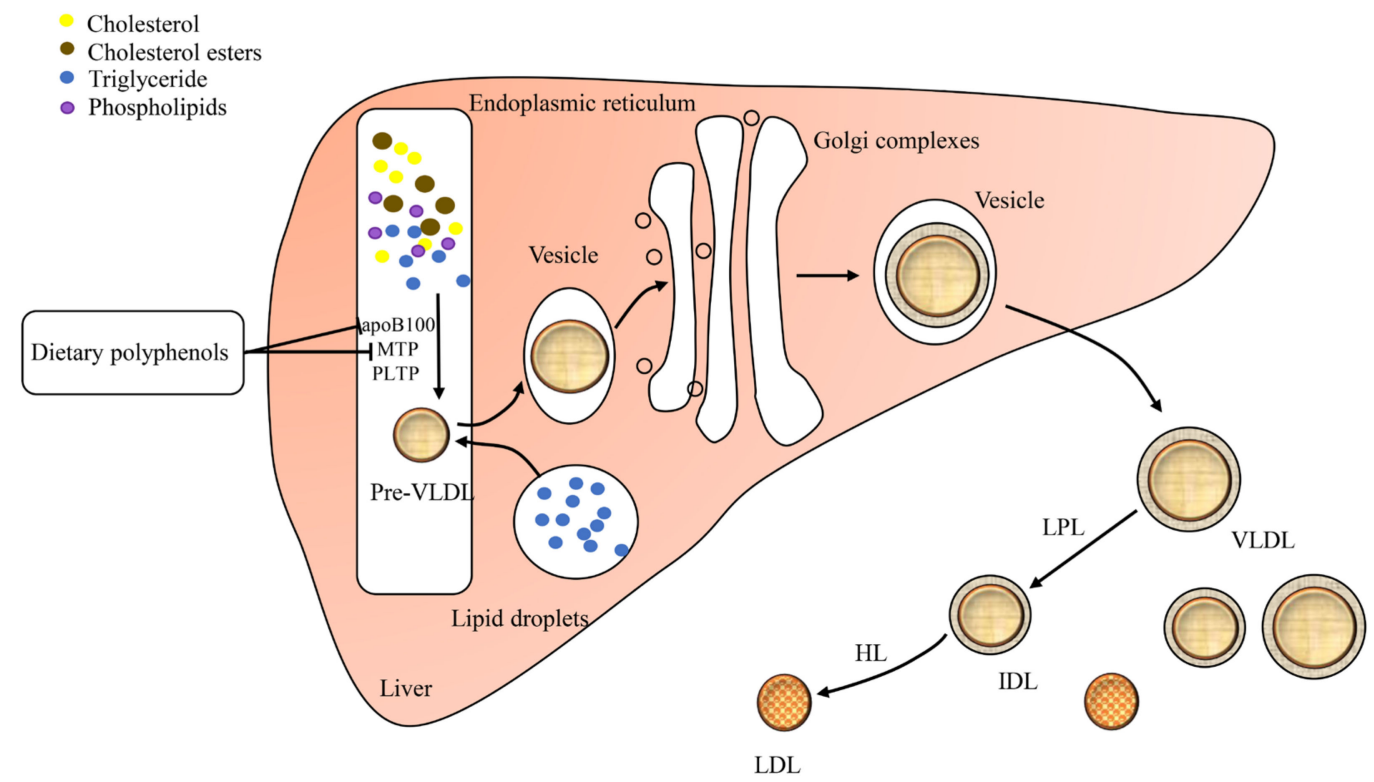

Figure 2. VLDL assembly and secretion. PLTP, phospholipid transfer protein; VLDL, very low-density lipoprotein; LPL, lipoprotein lipase; IDL, intermediate density lipoprotein; HL, hepatic lipase; LDL, low-density lipoprotein. 


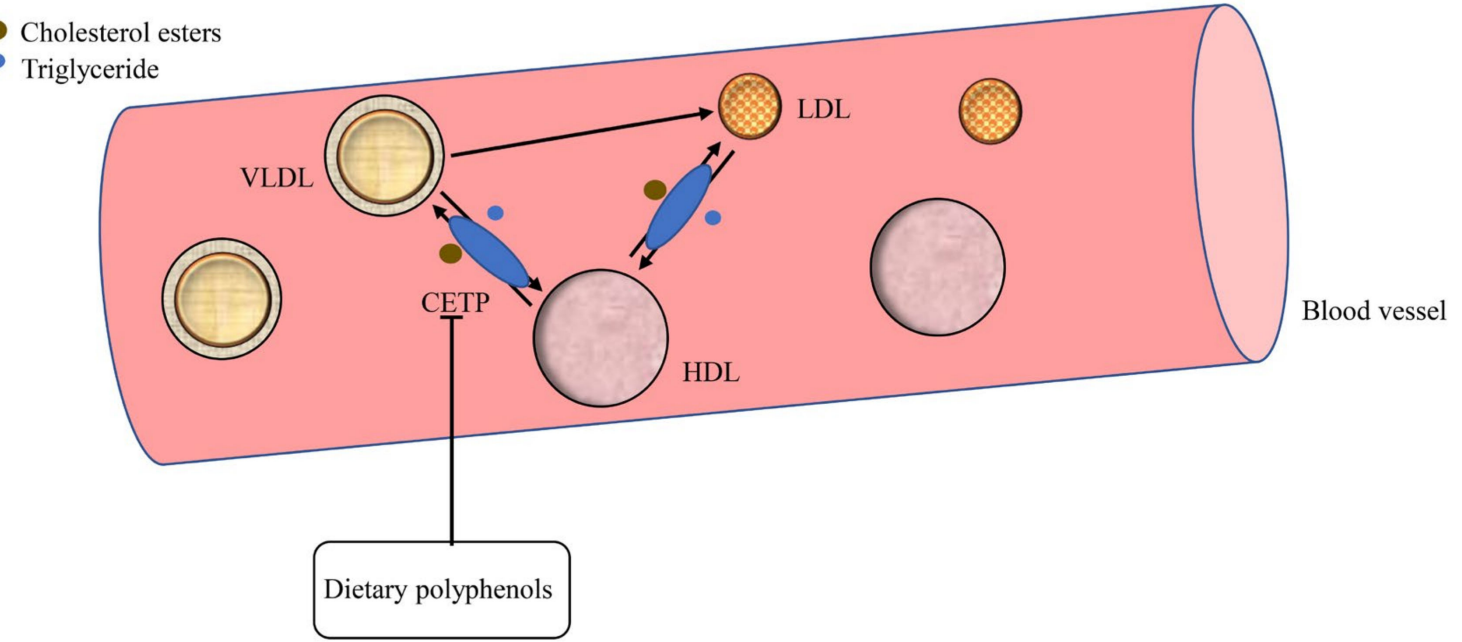

Figure 3. CETP-mediated LDL metabolism. CETP, cholesterol esters transfer protein; HDL, high-density lipoprotein.

\subsection{LDLR Mediates LDL Endocytosis}

LDLR is a multidomain transmembrane protein, which is responsible for removing $70 \%$ of LDL-C from plasma [43]. Consequently, increased hepatic LDLR expression results in improved clearance of plasma LDL-C. The LDLR adhering to the liver surface binds LDL in the blood and LDL-LDLR complexes are internalized (Figure 4) [44]. Following internalization, the complexes are trafficked to sorting early endosomes where LDL release occurs [45]. Meanwhile, LDLR is either recycled back to the cell surface or transported to the lysosomes for degradation [46]. Degradation of LDLR is respectively regulated by two proteins: IDOL (inducible degrader of the LDLR) and PCSK9 (proprotein convertase subtilisin/kexin type 9) (Figure 4) [47,48].

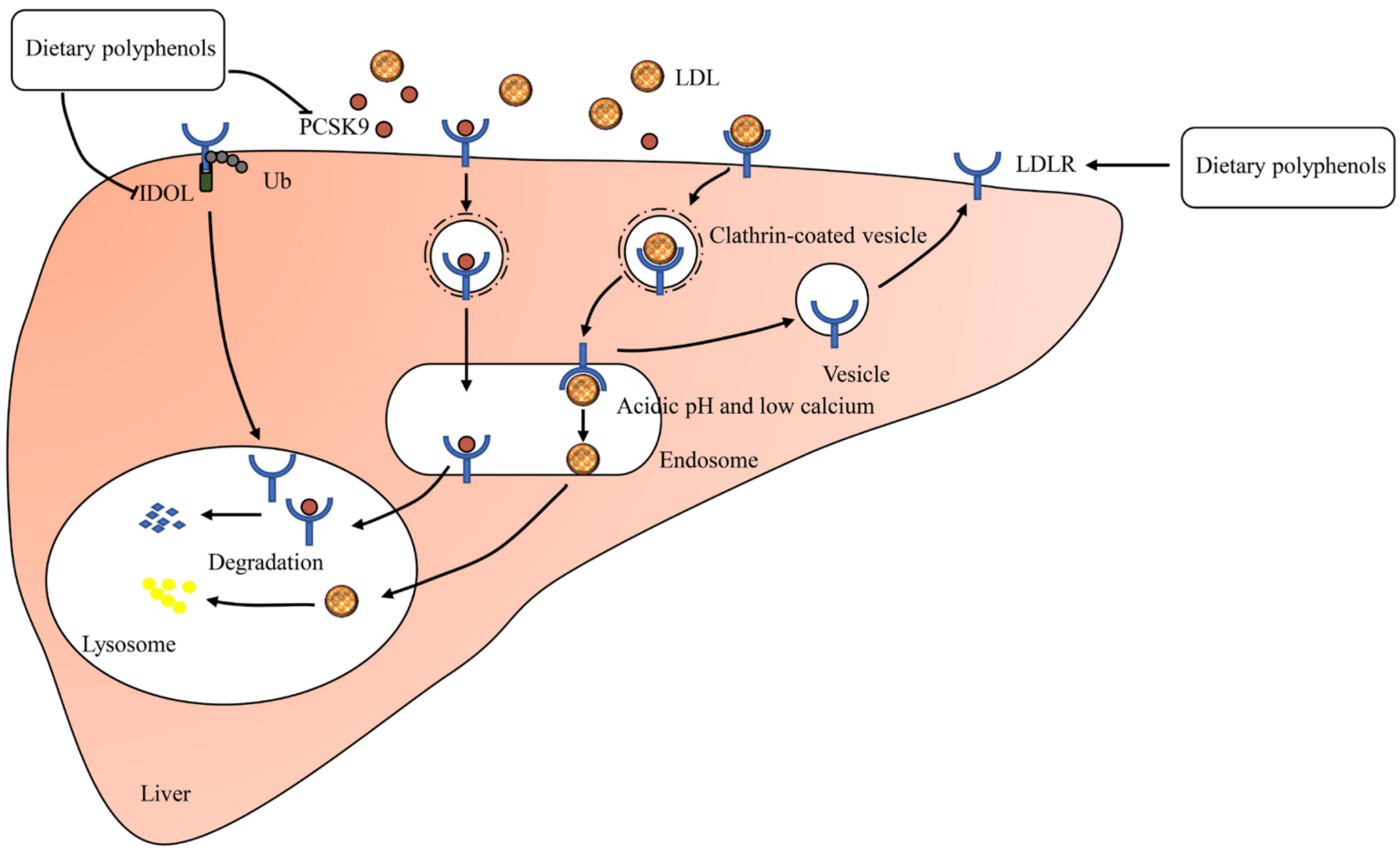

Figure 4. The regulatory mechanisms of LDL endocytosis. PCSK9, proprotein convertase subtilisin/kexin type 9; IDOL, inducible degrader of the LDLR; $\mathrm{Ub}$, ubiquitin. 


\subsection{Bile Acid Metabolism}

Bile acids, synthesized from cholesterol in hepatocytes, play a pivotal role in the absorption of dietary fats via the formation of micelles [49]. Hepatic cholesterol is transformed to bile acids via a variety of enzymes such as cholesterol $7 \alpha$-hydroxylase (CYP7A1), sterol 27-hydroxylase (CYP27A1), oxysterol $7 \alpha$-hydroxylase (CYP7B1), and so on (Figure 5) [50]. The newly synthesized bile acids are secreted to the canalicular space via the bile salt export pump (BSEP) to form bile [51]. Newly formed bile is stored in the gallbladder which is secreted into the duodenum in response to cholecystokinin [49]. A total of $95 \%$ of intestinal bile acids are reabsorbed via the apical sodium-dependent bile acid transporter (ASBT), the ileal bile acid binding protein (IBABP), and subsequently released into the portal vein through the organic solute transporters alpha and beta $(\mathrm{OST} \alpha / \mathrm{OST} \beta)[52,53]$. Hepatic uptake of bile acids is mediated by the sodium-dependent taurocholate co-transporting peptide (NTCP) and organic anion transporting polypeptides (OATPs) [52,54]. This recycling process is called enterohepatic circulation, which includes the liver, the biliary system, and the intestine [55]. Unabsorbed bile acids (about 5\%) are excreted in feces, which stimulates the de novo synthesis of bile acids from cholesterol in liver [56]. Consequently, decreased hepatic cholesterol causes more LDL-C absorption from plasma to the liver $[57,58]$.

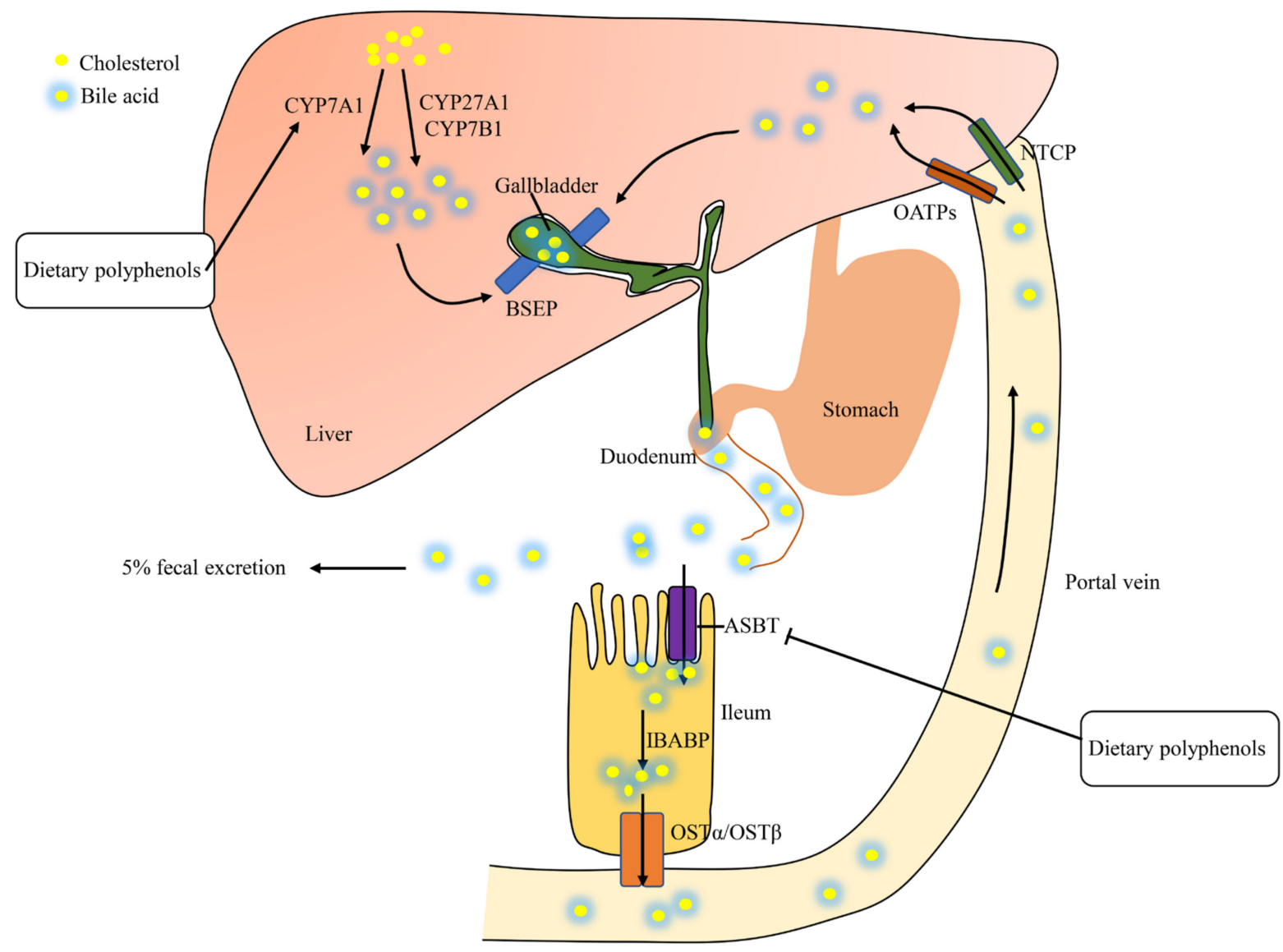

Figure 5. Enterohepatic circulation of bile acids. CYP7A1. cholesterol $7 \alpha$-hydroxylase; CYP27A1, sterol 27-hydroxylase; CYP7B1, oxysterol $7 \alpha$-hydroxylase; BSEP, bile salt export pump; OATPs, organic anion transporting polypeptides; NTCP, sodium-dependent taurocholate co-transporting peptide; ASBT, apical sodium-dependent bile acid transporter; IBABP, ileal bile acid binding protein; OST $\alpha /$ OST $\beta$, organic solute transporters alpha and beta.

\section{Current Strategies for LDL-C Lowering}

Up to now, numerous therapies have been developed to lower the LDL-C level. For example, statins are the first-line therapy in lowering LDL-C and can reduce the LDL-C level by about $60 \%$ [59]. Other strategies for LDL-C lowering include ezetimibe, bile acid se- 
questrants, anti-PCSK9 monoclonal antibodies (mAbs), bempedoic acid, squalene synthase inhibitors, mipomersen, lomitapide, ASBT inhibitors, and CETP inhibitors $[59,60]$. These strategies are mainly categorized into increasing the LDLR level, disturbing enterohepatic circulation, interfering VLDL assembly, and the CETP inhibitor [24,60-67]. Although these therapies are now reasonably effective, they have some shortcomings and adverse effects. For instance, anti-PCSK9 mAbs, mipomersen, and lomitapide are expensive, while statins and ezetimibe are relatively inexpensive as a series of generic drugs $[59,68]$. The long-term use of statins can also lead to muscle symptoms [69]. The details of current therapies are presented in Table 1.

Table 1. Current strategies for lowering the LDL-C level.

\begin{tabular}{|c|c|c|c|}
\hline Drug & Mechanism of Action & Adverse Effects & References \\
\hline Ezetimibe & $\begin{array}{l}\text { Inhibition of intestine } \\
\text { cholesterol absorption }\end{array}$ & - & [24] \\
\hline Mipomersen & ApoB synthesis inhibition & $\begin{array}{l}\text { Injection site reactions; Influenza-like } \\
\text { symptoms; Fatty liver }\end{array}$ & {$[61]$} \\
\hline Lomitapide & $\begin{array}{l}\text { Reduced secretion of apoB-containing } \\
\text { lipoproteins by MTP inhibition }\end{array}$ & $\begin{array}{l}\text { Gastrointestinal tract diarrhea, nausea, } \\
\text { vomiting, and dyspepsia; Fatty liver }\end{array}$ & {$[70,71]$} \\
\hline Statins & $\begin{array}{l}\text { Reduced hepatic cholesterol synthesis } \\
\text { and increased LDLR expression by } \\
\text { blocking hepatic } \\
\text { 3-hydroxy-3-methylglutaryl } \\
\text { coenzyme A reductase (HMGR) }\end{array}$ & $\begin{array}{l}\text { Statin-associated muscle symptoms } \\
\text { (myalgia, myopathy, and myositis with } \\
\text { elevated creatinine kinase } \\
\text { rhabdomyolysis) }\end{array}$ & {$[62,69]$} \\
\hline $\begin{array}{l}\text { Anti-PCSK9 monoclonal } \\
\text { antibodies (mAbs) }\end{array}$ & $\begin{array}{l}\text { Blockade of circulating PCSK9 } \\
\text { interaction with LDLR }\end{array}$ & Injection site reactions & [63] \\
\hline Bempedoic acid & $\begin{array}{l}\text { Reduced hepatic cholesterol synthesis } \\
\text { and increased LDLR expression by } \\
\text { blocking ATP-citrate lyase (ACLY) }\end{array}$ & $\begin{array}{l}\text { Elevated uric acid levels; Tendon } \\
\text { rupture; Increased serum creatinine }\end{array}$ & [59] \\
\hline Bile acid sequestrants & $\begin{array}{l}\text { Reduced bile acid reabsorption and } \\
\text { increased fecal elimination }\end{array}$ & $\begin{array}{l}\text { Gastrointestinal side effects: } \\
\text { constipation, bloating, abdominal } \\
\text { discomfort, and aggravation } \\
\text { of hemorrhoids }\end{array}$ & {$[64,72]$} \\
\hline CETP inhibitors & Inhibition of CETP & $\begin{array}{l}\text { Increase of plasma aldosterone and } \\
\text { blood pressure }\end{array}$ & {$[60]$} \\
\hline Squalene synthase inhibitors & $\begin{array}{l}\text { Reduced hepatic cholesterol synthesis } \\
\text { and increased LDLR expression by } \\
\text { blocking squalene synthase }\end{array}$ & $\begin{array}{l}\text { Acidosis; Elevation of alanine } \\
\text { aminotransferase and total bilirubin }\end{array}$ & {$[66,73]$} \\
\hline ASBT inhibitors & Reduced bile acid reabsorption & Abdominal pain and diarrhea & [67] \\
\hline
\end{tabular}

\section{Dietary Polyphenols: Potential LDL-C Lowering Agents}

As previously mentioned, some therapies lowering the LDL-C level are effective but associated with adverse effects. Hence, alternative strategies are needed to reduce the high level of LDL-C effectively without any adverse effect. In recent years, dietary polyphenols have received much attention in diseases prevention due to their potential therapeutic effects. Dietary polyphenols are a class of phytochemicals containing phenol rings, mainly from fruits, vegetables, legumes, cereals, nuts, plant-derived beverages, and chocolate $[13,74]$. From the last few decades, numerous studies have suggested that dietary polyphenols have exhibited the potential of reducing plasma LDL-C levels [75-77]. In a recent animal study, polyphenols-rich Perilla frutescens leaf extracts $(250 \mathrm{mg} / \mathrm{kg}$ body weight (bw)) were orally administrated to high-fat-diet-fed rats for 4 weeks. The results revealed that Perilla frutescens significantly reduced the plasma LDL-C level by $53 \%(p<0.05)$ [78]. In an animal model study conducted by $\mathrm{Li}$ and colleagues revealed that the decrease 
of the plasma LDL-C content by $45 \%$ in the onion-fed group was associated with the inhibition of HMGR and the upregulation of LDLR expression, which was a plausible mechanism for its LDL-C lowering effect. Researchers concluded that this effect was due to the presence of quercetin and isoquercitrin in onion [79]. Polyphenols-rich grape extract capsules (300 mg/day) were orally given to obese individuals for a period of 12 weeks. The results predicted that grape extracts decreased the plasma LDL-C level from $131 \pm 4.98$ to $110.28 \pm 5.8 \mathrm{mg} / \mathrm{dl}$ [80]. Luteolin, a bioactive compound present in chrysanthemum, was evaluated for its LDL-C lowering effect on hyperlipidemia rats. Luteolin $(50 \mathrm{mg} / \mathrm{kg}$ bw) was orally given to male Sprague Dawley rats for 6 weeks. The results divulged that luteolin reduced the level of plasma LDL-C by $34 \%$ and increased the liver CYP7A1 activity in rats [81]. In this section, we will review the effect of diets rich in polyphenols on lowering LDL-C and focus on the underlying molecular mechanism of LDL-C lowering by dietary polyphenols based on in vitro or in vivo models.

\subsection{Diets Rich in Polyphenols}

Polyphenol supplementation in numerous studies contained mainly extracts (mulberry water extracts, aloe vera extracts, green tea extract, grape extract, etc.), juices (raspberry juice, apple juice, and chokeberry juice), wines, and an increased intake of polyphenolrich foods (cacao, blueberry, and bilberry). In Tables 2 and 3, we will focus on research published from 2011 to 2021 about the effect of polyphenol consumption on lowering LDL-C in animal and clinical studies, respectively.

Table 2. Dietary sources, polyphenols, and cholesterol-lowering activities in animal models.

\begin{tabular}{|c|c|c|c|c|c|}
\hline Dietary Sources & $\begin{array}{l}\text { Polyphenols } \\
\text { Components }\end{array}$ & Treatment & Effect & $\begin{array}{c}p \text {-Value } \\
\text { (vs. Model) }\end{array}$ & References \\
\hline $\begin{array}{c}\text { White tea } \\
\text { (Camellia sinensis) }\end{array}$ & - & $\begin{array}{c}0.5 \% \text { aqueous extracts of } \\
\text { white tea to diabetes rats for } \\
4 \text { weeks }\end{array}$ & $\begin{array}{l}\text { Decreases in } \\
\text { plasma LDL-C }\end{array}$ & $p<0.05$ & [82] \\
\hline $\begin{array}{c}\text { Green tea } \\
\text { (Camellia sinensis) }\end{array}$ & $\begin{array}{l}\text { Epigallocatechin gallate, } \\
\text { epicatechin, epicatechin } \\
\text { gallate, epigallocatechin, } \\
\text { gallocatechin gallate, } \\
\text { and catechin }\end{array}$ & $\begin{array}{l}0.2 \% \text { green } \\
\text { tea extract was given to } \\
\text { atherogenic-diet-fed to SD } \\
\text { rats for } 4 \text { weeks }\end{array}$ & $\begin{array}{l}\text { Decreases in } \\
\text { plasma LDL-C } \\
\text { by } 40 \%\end{array}$ & $p<0.05$ & [83] \\
\hline $\begin{array}{l}\text { Fuzhuan brick } \\
\text { tea } \\
\text { (Camellia sinensis) }\end{array}$ & $\begin{array}{l}\text { Catechin, epicatechin, } \\
\text { epigallocatechin, } \\
\text { gallocatechin gallate, } \\
\text { epigallocatechin gallate, } \\
\text { epicatechin, gallate, } \\
\text { rutin, gallic acid, and } \\
\text { chlorogenic acid }\end{array}$ & $\begin{array}{c}75 \mathrm{mg} / \mathrm{kg}, 300 \mathrm{mg} \text { Fuzhuan } \\
\text { brick tea water extract } / \mathrm{kg} \\
\text { bw were given to obese rats } \\
\text { for } 40 \text { days }\end{array}$ & $\begin{array}{l}\text { Reduction in } \\
\text { plasma LDL-C } \\
\text { by } 38 \%\end{array}$ & $p<0.05$ & [84] \\
\hline $\begin{array}{c}\text { Kombucha } \\
\text { (Camellia sinensis) }\end{array}$ & - & $\begin{array}{l}\text { Kombucha }(5 \mathrm{~mL} / \mathrm{kg} \mathrm{bw}) \\
\text { was given to } \\
\text { hypercholesterolemic-diet- } \\
\text { fed rats per day for } 16 \\
\text { weeks }\end{array}$ & $\begin{array}{l}\text { Decreases in } \\
\text { plasma LDL-C } \\
\text { by } 36 \%\end{array}$ & $p<0.05$ & [85] \\
\hline $\begin{array}{c}\text { Youcha } \\
\text { (Camellia sinensis) }\end{array}$ & - & $\begin{array}{c}1500 \mathrm{mg} / \mathrm{kg} \cdot \mathrm{bw} \text { Youcha } \\
\text { were respectively given to } \\
\text { hyperlipidemia rats for } 32 \\
\text { days }\end{array}$ & $\begin{array}{l}\text { Decreases in } \\
\text { plasma LDL-C } \\
\text { by } 24 \%\end{array}$ & $p>0.05$ & [86] \\
\hline $\begin{array}{c}\text { Sanglan tea } \\
\text { (Camellia sinensis) }\end{array}$ & $\begin{array}{l}15 \text { kinds of flavonoids } \\
\text { such as quercetin and } \\
\text { kaempferol }\end{array}$ & $\begin{array}{l}\text { Sanglan tea (200 mg/kg bw, } \\
\text { respectively) was given to } \\
\text { obese mice for } 28 \text { weeks }\end{array}$ & $\begin{array}{l}\text { Reduction in } \\
\text { plasma LDL-C }\end{array}$ & $p<0.05$ & [87] \\
\hline $\begin{array}{c}\text { Oil tea } \\
\text { (Camellia sinensis) }\end{array}$ & - & $\begin{array}{l}4 \mathrm{~g} / \mathrm{kg} \text { bw oil tea was given } \\
\text { to type } 2 \text { diabetic mice }\end{array}$ & $\begin{array}{l}\text { Lowers plasma } \\
\text { LDL-C }\end{array}$ & $p<0.05$ & [88] \\
\hline
\end{tabular}


Table 2. Cont

\begin{tabular}{|c|c|c|c|c|c|}
\hline Dietary Sources & $\begin{array}{l}\text { Polyphenols } \\
\text { Components }\end{array}$ & Treatment & Effect & $\begin{array}{c}p \text {-Value } \\
\text { (vs. Model) }\end{array}$ & References \\
\hline $\begin{array}{c}\text { Bowl tea } \\
\text { (Camellia sinensis) }\end{array}$ & $\begin{array}{c}\text { Gallic acid, } \\
\text { epigallocatechin, catechin, } \\
\text { L-epicatechin, } \\
\text { epigallocatechin gallate, } \\
\text { gallocatechin gallate, and } \\
\text { epicatechin gallate }\end{array}$ & $\begin{array}{l}\text { Bowl tea }(50 \mathrm{mg} / \mathrm{kg} \mathrm{bw}) \\
\text { was given to } \\
\text { high-fat-diet-fed mice for } \\
12 \text { weeks }\end{array}$ & $\begin{array}{l}\text { Decreases in } \\
\text { plasma LDL-C } \\
\text { by } 24 \%\end{array}$ & $p<0.05$ & [89] \\
\hline $\begin{array}{c}\text { Persimmon } \\
\text { (Diospyros kaki) } \\
\text { wine and Grape } \\
\text { (Vitis vinifera) } \\
\text { wine }\end{array}$ & $\begin{array}{c}\text { Persimmon wine: } \\
\text { epicatechin, } \\
\text { epigallocatechin-gallate; } \\
\text { Grape wine: catechin, } \\
\text { epicatechin, } \\
\text { epicatechin-3-O-gallate, } \\
\text { and } \\
\text { epigallocatechin-gallate }\end{array}$ & $\begin{array}{l}\text { Wine }(7.4 \mathrm{ml} / \mathrm{kg} \mathrm{bw}) \text { to } \\
\text { atherogenic-diet-fed } \\
\text { hamsters for } 12 \text { weeks }\end{array}$ & $\begin{array}{l}\text { Decreases in } \\
\text { plasma LDL-C } \\
\text { levels by } 38 \%\end{array}$ & $p<0.05$ & [75] \\
\hline $\begin{array}{c}\text { Yellow wine } \\
\text { (Oryza sativa L.) }\end{array}$ & - & $\begin{array}{l}\text { Yellow wine polyphenolic } \\
\text { compounds ( } 30 \mathrm{mg} / \mathrm{kg} \\
\text { bw) were given to LDL } \\
\text { receptor knockout mice } \\
\text { per day for } 14 \text { weeks }\end{array}$ & $\begin{array}{l}\text { Decreases in } \\
\text { plasma LDL-C } \\
\text { by } 41 \%\end{array}$ & $p<0.05$ & [90] \\
\hline $\begin{array}{c}\text { Mulberry } \\
\text { (Morus alba L.) }\end{array}$ & $\begin{array}{l}\text { Gallic acid, protocatechuic } \\
\text { acid, 3-caffeoylquinic acid, } \\
\text { chlorogenic acid, } \\
\text { 4-caffeoyl quinic acid, } \\
\text { caffeic acid, rutin, and } \\
\text { quercetin-3-O-glucoside }\end{array}$ & $\begin{array}{c}0.5 \%, 1 \% \text {, and } 2 \% \\
\text { mulberry water extracts } \\
\text { were given to } \\
\text { high-fat-diet-fed hamsters } \\
\text { for } 12 \text { weeks }\end{array}$ & $\begin{array}{c}\text { Lowers } \\
\text { plasma LDL-C }\end{array}$ & $p<0.05$ & [91] \\
\hline $\begin{array}{c}\text { Raspberry } \\
\text { (Rubus idaeus) } \\
\text { juice }\end{array}$ & $\begin{array}{l}\text { Anthocyanins, } \\
\text { ellagitannins, and ellagic } \\
\text { acid-like compounds }\end{array}$ & $\begin{array}{c}\text { Equivalent to a } \\
\text { consumption of } 275 \\
\mathrm{~mL} / \text { day by a } 70 \mathrm{~kg} \text { human } \\
\text { to hypercholesterolemic } \\
\text { golden Syrian hamsters } \\
\text { for } 12 \text { weeks }\end{array}$ & $\begin{array}{l}\text { Decreases in } \\
\text { plasma LDL-C } \\
\text { by } 41 \%\end{array}$ & $p<0.05$ & [92] \\
\hline $\begin{array}{l}\text { Bilberry } \\
\text { (Vaccinuim } \\
\text { myrtillus) }\end{array}$ & $\begin{array}{c}\text { Anthocyanins, } \\
\text { quercetin-3-O-glucoside, } \\
\text { and chlorogenic acid }\end{array}$ & $\begin{array}{l}5 \mathrm{~g} \text { bilberry powder orally } \\
\text { given to Zucker diabetic } \\
\text { fatty rats for } 8 \text { weeks }\end{array}$ & $\begin{array}{l}\text { Ameliorates } \\
\text { LDL-C level } \\
\text { by } 60 \%\end{array}$ & $p<0.05$ & [8] \\
\hline $\begin{array}{l}\text { Berry (Lonicera } \\
\text { caerulea L. } \\
\text { var. edulis) }\end{array}$ & $\begin{array}{l}\text { Cyanidin-3-glucoside, } \\
\text { catechin, and } \\
\text { chlorogenic acid }\end{array}$ & $\begin{array}{l}\text { Lonicera caerulea berry } \\
\text { extract }(300 \mathrm{mg} / \mathrm{kg} \text { bw }) \\
\text { was given to } \\
\text { high-fat-diet-fed rats for } \\
\quad 12 \text { weeks }\end{array}$ & $\begin{array}{l}\text { Decreases in } \\
\text { plasma LDL-C } \\
\text { by } 48 \%\end{array}$ & $p<0.05$ & [93] \\
\hline $\begin{array}{l}\text { White bayberry } \\
\text { (Morella rubra } \\
\text { Sieb. et Zucc.) }\end{array}$ & $\begin{array}{l}\text { Epigallocatechin gallate, } \\
\text { epigallocatechin, } \\
\text { myricetin-3-O- } \alpha-1- \\
\text { rhamnoside, } \\
\text { quercetin-3-O- } \\
\text { rhamnoside, and } \\
\text { kaempferol-3-O- } \\
\text { rhamnoside }\end{array}$ & $\begin{array}{l}200 \mathrm{mg} / \mathrm{kg} \text { bw white } \\
\text { bayberry fruit extracts } \\
\text { were given to diabetic } \\
\text { KK-Ay mice } \\
\text { for } 5 \text { weeks }\end{array}$ & $\begin{array}{l}\text { Ameliorates } \\
\text { plasma LDL-C } \\
\text { by } 58 \%\end{array}$ & $p<0.05$ & [94] \\
\hline $\begin{array}{l}\text { Kiwifruit } \\
\text { (Actinidia } \\
\text { deliciosa) }\end{array}$ & - & $\begin{array}{l}5 \% \text { of lyophilized } \\
\text { kiwifruits were given to } \\
\text { atherogenic-diet-fed rats } \\
\text { for } 33 \text { days }\end{array}$ & $\begin{array}{l}\text { Decreases in } \\
\text { plasma LDL-C } \\
\text { by } 41 \%\end{array}$ & $p<0.05$ & [95] \\
\hline
\end{tabular}


Table 2. Cont.

\begin{tabular}{|c|c|c|c|c|c|}
\hline Dietary Sources & $\begin{array}{l}\text { Polyphenols } \\
\text { Components }\end{array}$ & Treatment & Effect & $\begin{array}{c}p \text {-Value } \\
\text { (vs. Model) }\end{array}$ & References \\
\hline Tamarindus indica & - & $\begin{array}{l}500 \mathrm{mg} \text { Tamarindus indica } \\
\text { fruit pulp extract } / \mathrm{kg} \text { bw } \\
\text { to } \\
\text { high-cholesterol-diet-fed } \\
\text { hamsters for } 10 \text { weeks }\end{array}$ & $\begin{array}{l}\text { Lowers plasma } \\
\text { LDL-C by } 60 \%\end{array}$ & $p<0.05$ & [96] \\
\hline $\begin{array}{c}\text { Apple } \\
\text { (Malus ssp.) }\end{array}$ & - & $\begin{array}{c}\text { Apple polyphenols } \\
(100 \mathrm{mg} / \mathrm{kg} \mathrm{bw}) \text { were } \\
\text { given to apolipoprotein-E } \\
\text { deficient }\left(\mathrm{ApoE}^{-/-}\right) \text {mice } \\
\text { for } 12 \text { weeks }\end{array}$ & $\begin{array}{l}\text { Decreases in } \\
\text { plasma LDL-C }\end{array}$ & $p<0.05$ & [97] \\
\hline $\begin{array}{l}\text { Apple (Malus) } \\
\text { juice }\end{array}$ & $\begin{array}{c}\text { Cloudy apple juice: } \\
\text { emodin, kaempferol, } \\
\text { cyanidin cation, } \\
\text { stevioside, and butylated } \\
\text { hydroxytoluene }\end{array}$ & $\begin{array}{l}\text { Cloudy apple juice } \\
(15 \mathrm{ml} / \mathrm{kg} \text { bw) was given } \\
\text { to diabetic rats for } 21 \text { days }\end{array}$ & $\begin{array}{l}\text { Decreases in } \\
\text { plasma LDL-C } \\
\text { by } 74 \%\end{array}$ & $p<0.05$ & [98] \\
\hline $\begin{array}{l}\text { Hawthorn } \\
\text { (Crataegus } \\
\text { oxyacantha) }\end{array}$ & $\begin{array}{l}\text { Chlorogenic acid, } \\
\text { epicatechin, rutin, } \\
\text { and hyperoside }\end{array}$ & $\begin{array}{l}400 \mathrm{mg} / \mathrm{kg} \text { bw extracts } \\
\text { from hawthorn fruit peel } \\
\text { and flesh were } \\
\text { respectively given to } \\
\text { high-fructose-diet-fed } \\
\text { mice for } 8 \text { weeks }\end{array}$ & $\begin{array}{l}\text { Reduction in } \\
\text { plasma LDL-C } \\
\text { by } 39 \%\end{array}$ & $p<0.05$ & [99] \\
\hline $\begin{array}{c}\text { Ajwa date } \\
\text { (Phoenix } \\
\text { dactylifera L.) }\end{array}$ & - & $\begin{array}{c}\text { Ajwa date extract } \\
\text { (25 mg/ } \mathrm{kg} \text { bw) was given } \\
\text { to hypercholestrolemic } \\
\text { rats for } 28 \text { days }\end{array}$ & $\begin{array}{l}\text { Ameliorates } \\
\text { plasma LDL-C }\end{array}$ & $p<0.05$ & [100] \\
\hline Hibiscus sabdariffa & $\begin{array}{l}18 \text { phenolic } \\
\text { compounds }\end{array}$ & $\begin{array}{c}100 \mathrm{mg} / \mathrm{kg} \text { bw Hibiscus } \\
\text { sabdariffa polyphenolic } \\
\text { extract to diabetic rats for } \\
7 \text { weeks }\end{array}$ & $\begin{array}{c}\text { Reduction in } \\
\text { plasma } \\
\text { LDL/HDL ratio }\end{array}$ & $p<0.05$ & [101] \\
\hline Hibiscus sabdariffa & $\begin{array}{c}\text { Protocatechuic acid, } \\
\text { catechin, gallocatechins, } \\
\text { caffeic acid, and } \\
\text { gallocatechin gallates }\end{array}$ & $\begin{array}{l}0.5 \% \text { Hibiscus sabdariffa } \\
\text { extract were given to } \\
\text { obese hamsters for } \\
10 \text { weeks }\end{array}$ & $\begin{array}{l}\text { Ameliorates } \\
\text { plasma LDL-C }\end{array}$ & $p<0.05$ & [102] \\
\hline Propolis & $\begin{array}{l}\text { Green propolis: artepellin } \\
\text { c, pinocembrin, and } \\
\text { kampferol; } \\
\text { Red propolis: } \\
\text { 3-Hydroxy-8,9- } \\
\text { dimethoxypterocarpan, } \\
\text { medicarpin, and daidzein; } \\
\text { Brown propolis: } \\
\text { pinocembrin, caffeic acid } \\
\text { phenyl ester, quercetin, } \\
\text { and galangin }\end{array}$ & $\begin{array}{l}\text { Green, red, or brown } \\
\text { propolis extract } \\
(250 \mathrm{mg} / \mathrm{kg} \text { bw }) \text { to } \\
\text { cholesterol-enriched-diet- } \\
\text { fed LDLR knockout mice } \\
\text { for } 4 \text { weeks }\end{array}$ & $\begin{array}{l}\text { Reduces plasma } \\
\text { non-HDL-C } \\
\text { treated with the } \\
\text { red propolis } \\
\text { by } 17 \%\end{array}$ & $p<0.05$ & [103] \\
\hline Aloe vera & - & $\begin{array}{l}1.25 \mathrm{~g} \text { Aloe vera } \\
\text { extracts } / \mathrm{kg} \text { bw was given } \\
\text { to type } 2 \text { diabetic rats for } \\
28 \text { days }\end{array}$ & $\begin{array}{l}\text { Lowers plasma } \\
\text { LDL-C }\end{array}$ & $p>0.05$ & [104] \\
\hline $\begin{array}{l}\text { Adlay (Coix } \\
\text { lachryma-jobi L. } \\
\text { var. ma-yuen } \\
\text { Stapf) }\end{array}$ & Gallic acid and catechin & $\begin{array}{l}40 \mathrm{mg} \text { total phenolics } / \mathrm{kg} \\
\text { bw to } \\
\text { high-cholesterol-diet-fed } \\
\text { rats for } 28 \text { days }\end{array}$ & $\begin{array}{l}\text { Decreases in } \\
\text { plasma LDL-C } \\
\text { by } 30 \%\end{array}$ & $p<0.05$ & [105] \\
\hline
\end{tabular}


Table 2. Cont.

\begin{tabular}{|c|c|c|c|c|c|}
\hline Dietary Sources & $\begin{array}{l}\text { Polyphenols } \\
\text { Components }\end{array}$ & Treatment & Effect & $\begin{array}{c}p \text {-Value } \\
\text { (vs. Model) }\end{array}$ & References \\
\hline $\begin{array}{l}\text { Bergamot (Citrus } \\
\text { bergamia Risso et } \\
\text { Poiteau) }\end{array}$ & - & $\begin{array}{l}50 \mathrm{mg} / \mathrm{kg} \text { bw bergamot } \\
\text { polyphenolic formulation } \\
\text { was given to } \\
\text { high-fat-diet-fed mice for } \\
16 \text { weeks }\end{array}$ & $\begin{array}{l}\text { Reduction in } \\
\text { plasma LDL-C } \\
\text { by } 40 \%\end{array}$ & $p<0.05$ & [106] \\
\hline $\begin{array}{l}\text { Perilla. frutescens } \\
\text { (L.) Britt. }\end{array}$ & - & $\begin{array}{c}\text { Leaf extracts }(250 \mathrm{mg} / \mathrm{kg} \\
\text { bw) were given to } \\
\text { high-fat-diet-fed rats for } 4 \\
\text { weeks }\end{array}$ & $\begin{array}{l}\text { Lowers plasma } \\
\text { LDL-C by } 53 \%\end{array}$ & $p<0.05$ & [78] \\
\hline $\begin{array}{l}\text { Onion (Allium } \\
\text { cepa L.) }\end{array}$ & $\begin{array}{l}\text { Quercetin and } \\
\text { isoquercitrin }\end{array}$ & $\begin{array}{l}\text { Hyperlipidemic rats } \\
\text { treated with onion extract } \\
\text { at } 4.5 \mathrm{~g} / \mathrm{kg} \text { bw for } 4 \text { weeks }\end{array}$ & $\begin{array}{l}\text { Ameliorates } \\
\text { plasma LDL-C } \\
\text { by } 45 \%\end{array}$ & $p<0.05$ & [79] \\
\hline $\begin{array}{l}\text { Rhodomyrtus } \\
\text { tomentosa fruit } \\
\text { juice }\end{array}$ & - & $\begin{array}{l}2 \mathrm{~g} / \mathrm{kg} \mathrm{bw} \text { frozen fruit } \\
\text { juice was given to } \\
\text { high-fat-diet-fed rats for } \\
75 \text { days }\end{array}$ & $\begin{array}{c}\text { Reduces plasma } \\
\text { LDL-C }\end{array}$ & $p<0.05$ & [107] \\
\hline Astragalus radix & - & $\begin{array}{l}25 \mathrm{mg} \text { Astragalus radix } \\
\text { total flavones } / \mathrm{kg} \text { bw was } \\
\text { given to diabetic mice for } \\
\text { 8 weeks }\end{array}$ & $\begin{array}{l}\text { Lowers plasma } \\
\text { LDL-C }\end{array}$ & $p<0.05$ & [108] \\
\hline $\begin{array}{c}\text { Turmeric } \\
\text { (Curcuma longa) }\end{array}$ & - & $\begin{array}{l}2.0 \% \text { turmeric powder was } \\
\text { given to high-fat-diet-fed } \\
\text { mice for } 8 \text { weeks }\end{array}$ & $\begin{array}{l}\text { Lowers plasma } \\
\text { LDL-C }\end{array}$ & $p<0.05$ & [109] \\
\hline $\begin{array}{l}\text { Schinus } \\
\text { terebinthifolius } \\
\text { Raddi }\end{array}$ & $\begin{array}{l}\text { Gallic acid, catechin, } \\
\text { naringenin, and } \\
\text { kaempferol }\end{array}$ & $\begin{array}{c}50 \mathrm{mg} \text { Schinus } \\
\text { terebinthifolius Raddi } \\
\text { extract } / \mathrm{kg} \text { bw to } \\
\text { high-cholesterol-diet-fed } \\
\text { rats for } 9 \text { weeks }\end{array}$ & $\begin{array}{c}\text { Ameliorates } \\
\text { plasma LDL-C by } \\
41 \%\end{array}$ & $p<0.05$ & [110] \\
\hline
\end{tabular}

Table 3. Dietary sources, polyphenols, and cholesterol-lowering activities in clinical studies.

\begin{tabular}{|c|c|c|c|c|c|}
\hline Dietary Sources & $\begin{array}{l}\text { Polyphenols } \\
\text { Components }\end{array}$ & Treatment & Effect & $p$-Value & References \\
\hline $\begin{array}{c}\text { Green tea } \\
\text { (Camellia sinesis) }\end{array}$ & $\begin{array}{l}\text { Epigallocatechin gallate, } \\
\text { epicatechin, } \\
\text { epigallocatechin, } \\
\text { epicatechin gallate, and } \\
\text { gallocatechin gallate }\end{array}$ & $\begin{array}{l}\text { Green tea capsules were } \\
\text { given to healthy } \\
\text { postmenopausal women } \\
\text { for } 2 \text { months }\end{array}$ & $\begin{array}{l}\text { Reduction in } \\
\text { plasma LDL-C by } \\
8 \% \text { from baseline }\end{array}$ & $\begin{array}{c}p<0.05 \\
\text { (vs. placebo } \\
\text { group) }\end{array}$ & [76] \\
\hline $\begin{array}{c}\text { Green tea } \\
\text { (Camellia sinesis) }\end{array}$ & $\begin{array}{l}\text { Epigallocatechin gallate, } \\
\text { epicatechin gallate, } \\
\text { epigallocatechin, } \\
\text { epicatechin, and } \\
\text { gallocatechin gallate }\end{array}$ & $\begin{array}{l}1500 \mathrm{mg} \text { green tea } \\
\text { extract was given to } \\
\text { women with central } \\
\text { obesity for } 12 \text { weeks }\end{array}$ & $\begin{array}{l}\text { Decreases in } \\
\text { plasma LDL-C by } \\
10 \% \text { from baseline }\end{array}$ & $\begin{array}{c}\quad p<0.05 \\
\text { (vs. baseline) }\end{array}$ & [111] \\
\hline $\begin{array}{c}\text { Green tea } \\
\text { (Camellia sinesis) }\end{array}$ & $\begin{array}{c}\text { Epigallocatechin } \\
\text { 3-gallate, } \\
\text { epigallocatechin, } \\
\text { catechin, epicatechin, } \\
\text { gallocatechin gallate, } \\
\text { and } \\
\text { epicatechin-3-gallate }\end{array}$ & $\begin{array}{c}1500 \text { mg STA-2 (a } \\
\text { pharmaceutical } \\
\text { preparation of green tea } \\
\text { polyphenols) } \\
\text { daily was given to } \\
\text { patients with chronic } \\
\text { stable angina for } 6 \\
\text { weeks }\end{array}$ & $\begin{array}{l}\text { Decreases in } \\
\text { plasma LDL-C }\end{array}$ & $\begin{array}{c}p<0.05 \\
\text { (vs. placebo } \\
\text { group) }\end{array}$ & [112] \\
\hline
\end{tabular}


Table 3. Cont.

\begin{tabular}{|c|c|c|c|c|c|}
\hline Dietary Sources & $\begin{array}{l}\text { Polyphenols } \\
\text { Components }\end{array}$ & Treatment & Effect & $p$-Value & References \\
\hline $\begin{array}{c}\text { Green tea } \\
\text { (Camellia sinesis) }\end{array}$ & $\begin{array}{l}\text { Catechins and } \\
\text { epigallocatechin-3- } \\
\text { gallate }\end{array}$ & $\begin{array}{l}400 \mathrm{mg} \text { of decaffeinated } \\
\text { green tea extract daily } \\
\text { was given to patients } \\
\text { with type } 2 \text { diabetes } \\
\text { mellitu for } 12 \text { weeks }\end{array}$ & $\begin{array}{l}\text { Decreases in } \\
\text { plasma LDL-C by } \\
9 \% \text { from baseline }\end{array}$ & $\begin{array}{c}p>0.05 \\
\text { (vs. placebo } \\
\text { group) }\end{array}$ & {$[113]$} \\
\hline $\begin{array}{c}\text { Goishi tea } \\
\text { (Camellia sinesis) }\end{array}$ & - & $\begin{array}{c}195 \mathrm{ml} \text { Goishi tea drink } \\
\text { was given to } \\
\text { hypercholesterolaemia } \\
\text { individuals for } 12 \text { weeks }\end{array}$ & $\begin{array}{l}\text { No changes in } \\
\text { plasma LDL-C }\end{array}$ & $\begin{array}{c}p>0.05 \\
\text { (vs. placebo } \\
\text { group) }\end{array}$ & {$[114]$} \\
\hline $\begin{array}{c}\text { Red wine } \\
\text { (Vitis vinifera L.) }\end{array}$ & Resveratrol & $\begin{array}{c}2 \text { capsules daily } \\
\text { nonalcoholic red wine } \\
\text { extract were given to } \\
\text { nondiabetic humans for } \\
8 \text { weeks }\end{array}$ & $\begin{array}{l}\text { Decreases in } \\
\text { plasma LDL-C by } \\
4 \% \text { from baseline }\end{array}$ & $\begin{array}{c}p<0.05 \\
\text { (vs. baseline) }\end{array}$ & {$[115]$} \\
\hline $\begin{array}{l}\text { Chokeberry } \\
\text { (Aronia } \\
\text { melanocarpa L.) } \\
\text { juice }\end{array}$ & $\begin{array}{l}\text { Cyanidin 3-galactoside, } \\
\text { cyanidin 3-arabinoside, } \\
\text { and cyanidin 3-xyloside }\end{array}$ & $\begin{array}{c}200 \mathrm{~mL} \text { chokeberry juice } \\
\text { given to hypertensive } \\
\text { subjects per day for } \\
4 \text { weeks }\end{array}$ & $\begin{array}{l}\text { Reduction in } \\
\text { plasma LDL-C by } \\
7 \% \text { from baseline }\end{array}$ & $\begin{array}{c}p>0.05 \\
\text { (vs. baseline) }\end{array}$ & [9] \\
\hline $\begin{array}{l}\text { Aronia berry } \\
\qquad(\text { Aronia } \\
\text { melanocarpa })\end{array}$ & $\begin{array}{l}\text { Anthocyanins, } \\
\text { hydroxycinnamic acids, } \\
\text { and proanthocyanidins }\end{array}$ & $\begin{array}{l}500 \mathrm{mg} \text { aronia extract } \\
\text { per day was given to } \\
\text { healthy adults for } \\
12 \text { weeks }\end{array}$ & $\begin{array}{l}\text { Reduction in } \\
\text { plasma LDL-C by } \\
11 \% \text { from baseline }\end{array}$ & $\begin{array}{c}p<0.05 \\
\text { (vs. placebo } \\
\text { group) }\end{array}$ & [116] \\
\hline $\begin{array}{l}\text { Blueberry } \\
\text { (Vaccinium } \\
\text { virgatum.) }\end{array}$ & - & $\begin{array}{l}22 \mathrm{~g} \text { freeze-dried } \\
\text { blueberries daily were } \\
\text { given to men with type } \\
2 \text { diabetes for } 8 \text { weeks }\end{array}$ & $\begin{array}{l}\text { Decreases in } \\
\text { plasma LDL-C by } \\
25 \% \text { from baseline }\end{array}$ & $\begin{array}{c}p<0.05 \\
\text { (vs. placebo } \\
\text { group) }\end{array}$ & [117] \\
\hline $\begin{array}{l}\text { Grape (Vitis } \\
\text { vinifera L.) }\end{array}$ & $\begin{array}{l}\text { Myricetin, quercetin, } \\
\text { catechin, epicatechin, } \\
\text { epigallocatechin, } \\
\text { catechin gallate, and } \\
\text { ellagic acid }\end{array}$ & $\begin{array}{l}700 \text { mg grape extract } \\
\text { was given to healthy } \\
\text { volunteers for } 56 \text { days }\end{array}$ & $\begin{array}{l}\text { Reduces plasma } \\
\text { LDL-C by } 15 \% \\
\text { from baseline }\end{array}$ & $\begin{array}{c}p<0.05 \\
\text { (vs. placebo } \\
\text { group) }\end{array}$ & [118] \\
\hline $\begin{array}{l}\text { Grape (Vitis } \\
\text { vinifera L.) }\end{array}$ & - & $\begin{array}{l}500 \text { g Condori red } \\
\text { grapes daily were given } \\
\text { to hypercholesterolemic } \\
\text { humans for } 8 \text { weeks }\end{array}$ & $\begin{array}{l}\text { Reduces plasma } \\
\text { LDL-C with grapes } \\
\text { treatment by } 15 \%\end{array}$ & $\begin{array}{c}p<0.01 \\
\text { (vs. baseline) }\end{array}$ & [119] \\
\hline $\begin{array}{l}\text { Grapefruit (Vitis } \\
\text { vinifera L.), bitter } \\
\text { orange (Citrus } \\
\text { aurantium Linné), } \\
\text { and olive (Olea } \\
\text { europaea) }\end{array}$ & $\begin{array}{l}\text { Naringin, narirutin, } \\
\text { rhoifolin, poncirin, } \\
\text { apigenin, neohesperidin, } \\
\text { neodiosmin, luteolin, } \\
\text { and oleuropein }\end{array}$ & $\begin{array}{c}1000 \text { mg grapefruit, } \\
\text { bitter orange, and olive } \\
\text { leaf extracts were given } \\
\text { to healthy subjects for } 8 \\
\text { weeks }\end{array}$ & $\begin{array}{l}\text { Reduces plasma } \\
\text { LDL-C by } 9 \% \text { from } \\
\text { baseline }\end{array}$ & $\begin{array}{c}p<0.05 \\
\text { (vs. placebo } \\
\text { group) }\end{array}$ & {$[120]$} \\
\hline $\begin{array}{l}\text { Grape (Vitis } \\
\text { vinifera L.) }\end{array}$ & - & $\begin{array}{l}\text { Overweight individuals } \\
\text { were assigned to receive } \\
\text { grape seed extract ( } 300 \\
\text { mg/day) for } 12 \text { weeks }\end{array}$ & $\begin{array}{l}\text { Reduces plasma } \\
\text { LDL-C by } 16 \% \\
\text { from baseline }\end{array}$ & $\begin{array}{c}p<0.05 \\
\text { (vs. placebo } \\
\text { group) }\end{array}$ & {$[80]$} \\
\hline $\begin{array}{c}\text { Olive (Olea } \\
\text { europaea) }\end{array}$ & - & $\begin{array}{l}250 \mathrm{mg} / \text { day olive } \\
\text { extract was given to } \\
\text { postmenopausal women } \\
\text { for } 12 \text { months }\end{array}$ & $\begin{array}{l}\text { Decreases in } \\
\text { plasma LDL-C by } \\
21 \% \text { from baseline }\end{array}$ & $\begin{array}{c}p<0.05 \\
\text { (vs. placebo } \\
\text { group) }\end{array}$ & {$[121]$} \\
\hline
\end{tabular}


Table 3. Cont.

\begin{tabular}{|c|c|c|c|c|c|}
\hline Dietary Sources & $\begin{array}{l}\text { Polyphenols } \\
\text { Components }\end{array}$ & Treatment & Effect & $p$-Value & References \\
\hline $\begin{array}{c}\text { Olive (Olea } \\
\text { europaea) }\end{array}$ & - & $\begin{array}{l}400 \mathrm{~g} \text { yogurt with } 50 \mathrm{mg} \\
\text { of encapsulated olive } \\
\text { polyphenols was given } \\
\text { to volunteers for } \\
2 \text { weeks }\end{array}$ & $\begin{array}{l}\text { Ameliorates } \\
\text { plasma LDL-C by } \\
6 \% \text { from baseline }\end{array}$ & $\begin{array}{c}p<0.05 \\
\text { (vs. baseline) }\end{array}$ & {$[122]$} \\
\hline $\begin{array}{l}\text { Pomegranate } \\
\text { (Punica } \\
\text { granatum L.) }\end{array}$ & Ellagic acid & $\begin{array}{l}1000 \mathrm{mg} \text { pomegranate } \\
\text { extract was given to } \\
\text { obese individuals for } \\
30 \text { days }\end{array}$ & $\begin{array}{l}\text { Reduction in } \\
\text { plasma LDL-C by } \\
10 \% \text { from baseline }\end{array}$ & $\begin{array}{c}p<0.01 \\
\text { (vs. baseline) }\end{array}$ & [123] \\
\hline $\begin{array}{c}\text { Pomegranate } \\
\text { (Punica granatum } \\
\text { L.) juice }\end{array}$ & - & $\begin{array}{l}200 \mathrm{~mL} / \text { day } \\
\text { pomegranate juice was } \\
\text { given to type } 2 \text { diabetes } \\
\text { patients for } 6 \text { weeks }\end{array}$ & $\begin{array}{l}\text { Reduces plasma } \\
\text { LDL-C by } 10 \% \\
\text { from baseline }\end{array}$ & $\begin{array}{c}p<0.05 \\
\text { (vs. baseline) }\end{array}$ & {$[124]$} \\
\hline $\begin{array}{l}\text { Cherry (Prunus } \\
\text { avium) juice }\end{array}$ & - & $\begin{array}{l}480 \mathrm{~mL} \text { cherry juice } \\
\text { drink daily to older } \\
\text { adults for } 12 \text { weeks }\end{array}$ & $\begin{array}{l}\text { Decreases in } \\
\text { plasma LDL-C by } \\
3 \% \text { from baseline }\end{array}$ & $\begin{array}{c}p<0.05 \\
\text { (vs. placebo } \\
\text { group) }\end{array}$ & {$[125]$} \\
\hline $\begin{array}{c}\text { Tart cherry } \\
\text { (Prunus cerasus) }\end{array}$ & $\begin{array}{c}\text { Cyanidin sophoroside, } \\
\text { cyanidin } \\
\text { glucosylrutinoside, } \\
\text { cyanidin-glucoside, } \\
\text { cyanidin } \\
\text { xylosylrutinoside, } \\
\text { cyanidin rutinoside, and } \\
\text { peonidin rutinoside }\end{array}$ & $\begin{array}{l}240 \mathrm{~mL} \text { of tart cherry } \\
\text { juice twice daily was } \\
\text { given to adults with } \\
\text { metabolic syndrome for } \\
12 \text { weeks }\end{array}$ & $\begin{array}{l}\text { Reduction in } \\
\text { plasma LDL-C by } \\
15 \% \text { from baseline }\end{array}$ & $\begin{array}{c}p>0.05 \\
\text { (vs. baseline) }\end{array}$ & {$[77]$} \\
\hline Ecklonia cava & $\begin{array}{c}\text { Dieckol, 8,8'-bieckol, } \\
\text { 6,6'-bieckol, and } \\
\text { phlorofurofucoeckol A }\end{array}$ & $\begin{array}{l}72 \mathrm{mg} \text { Ecklonia cava } \\
\text { polyphenols per day to } \\
\text { overweight } \\
\text { Korean individuals for } \\
12 \text { weeks }\end{array}$ & $\begin{array}{l}\text { Ameliorates } \\
\text { plasma LDL-C by } \\
10 \% \text { from baseline }\end{array}$ & $\begin{array}{c}p<0.05 \\
\text { (vs. placebo } \\
\text { group) }\end{array}$ & [126] \\
\hline
\end{tabular}

$p<0.05$ considered to be statistically significant.

\subsection{Flavonoids}

\subsubsection{Flavonols}

Quercetin is a common plant flavonol which is widely present in vegetables, fruits, tea, and red wine [127]. In plants, partial quercetin has existed in the form quercetin-3glucoside [128]. Quercetin exhibits favorable anti-atherosclerotic, anti-inflammatory, and antioxidant activities [129-131]. Interestingly, quercetin and its glycoside have attracted attention to the hypolipidemic effect [132-134]. In animal studies, treatment with quercetin and quercetin-3-glucoside significantly decreased the plasma LDL-C level in mice fed with a high-fat diet $[133,134]$. The quercetin group was administrated with quercetin in an aqueous solution through oral gavage with the dose of $12.5 \mathrm{mg} / \mathrm{kg}$ bw. Compared with the model group, the LDL-C level in quercetin group was reduced by $49 \%(p<0.01)$. A total of $0.05 \%$ quercetin-3-glucoside supplementation significantly reduced the LDL-C level in comparison with the high-fat-fed control group. In a human study involving 24 subjects with mild hypercholesterolemia, the LDL-C level was greatly reduced by $9.2 \%$ after consuming $500 \mathrm{~mL}$ of quercetin-rich onion juice for 10 weeks $(p<0.01)$ [135]. The mechanisms by which quercetin and its glycoside inhibited the LDL-C level may involve several aspects. Firstly, quercetin reduced cholesterol absorption. The expression of NPC1L1, a critical protein in cholesterol absorption, was decreased in Caco-2 cells treated with $100 \mu \mathrm{M}$ quercetin [136]. Secondly, both quercetin and its glycoside regulate LDLR expression. Moon demonstrated that $75 \mu \mathrm{M}$ of quercetin upregulated the LDLR expression in HepG2 cells via the enhanced processing of the sterol regulatory element-binding protein 
2 (SREBP2) following the sequential activation of c-Jun N-terminal kinases (JNK) and the extracellular signal-related kinase (ERK) signaling pathways [137]. In the Huh7 cells (human hepatocytes), treatment with $5 \mu \mathrm{M}$ quercetin-3-glucoside accelerated the LDL uptake by increasing LDLR expression and attenuating PCSK9 secretion [138]. Similarly, Mbikay's study showed that $0.05 \%$ quercetin-3-glucoside reduced PCSK9 secretion and increased the hepatic LDLR expression in mice fed with a high-cholesterol diet [134]. Thirdly, quercetin facilitates bile acid biosynthesis and excretion. In a Zhang's study, it was suggested that a dietary supplementation of $0.4 \%$ quercetin increased the excretion of fecal bile acid and the level of CYP7A1, a critical enzyme promoting cholesterol-to-bile acid conversion in bile acid biosynthesis [139].

\subsubsection{Flavan-3-ols}

Epigallocatechin-3-gallate (EGCG), which is an ester that forms through the reaction of epigallocatechin and gallic acid, is the major catechin in tea [140]. Substantial evidence suggests that EGCG elicit a wide range of properties, including antioxidant and antilipid deposition and anti-inflammation [141-143]. Extensive studies have shown that the consumption of EGCG exhibited an LDL-C reducing effect [144-147]. A systematic review found that EGCG could significantly decrease the plasma LDL-C level at doses between 107 and $856 \mathrm{mg} / \mathrm{d}$ [148-150]. Several mechanisms by which EGCG lowers the content of LDL-C involve cholesterol absorption, VLDL assembly, LDLR, and bile acid metabolism. Huang and colleagues [151] found that 0.32\% EGCG reduced LDL-C by $28 \%$ in mice fed with a high-fat diet by increasing the fecal excretion of bile acids and cholesterol and decreasing cholesterol and bile acid reabsorption. Raederstorff and colleagues [152] found that EGCG affected intestinal cholesterol absorption by interfering with the micellar solubilization of cholesterol in a dose-dependent manner. Researchers [145] have pointed out that the enhanced biliary secretion of cholesterol was associated with the increased expression of ABCG5/ABCG8 and the decreased expression of ACAT2 by EGCG at a dose of $50 \mathrm{mg} / \mathrm{kg} \mathrm{bw}$. Moreover, evidence indicated that EGCG could suppress the LDLC content by inducing an upregulation of LDLR [153]. A total of $25 \mu \mathrm{M}$ EGCG could upregulate the level of LDLR through the ERK signaling pathways and downregulate the expression of PCSK9 in the HepG2 cell model [153]. In an animal study [147], rats fed with high-fat diet supplementation with $50 \mathrm{mg} / \mathrm{kg}$ bw of EGCG could weaken the concentration of circulation PCSK9 and nuclear factor- $1 \alpha$ (HNF- $1 \alpha$ ) and the expression of PCSK9, as well as raise forkhead box class O (FoxO)3a and LDLR levels. Circulation PCSK9 could accelerate the degradation of LDLR, resulting in an elevated level of LDL$C$ in plasma [154]. HNF1 $\alpha$ and FoXO3a are two transcription factors that regulate the expression of PCSK9 [147]. Thereby, EGCG acts on HNF1 $\alpha$ and FoXO3a to reduce PCSK9 expression [147]. In a study by Kuhn, it was found that $1 \mu \mathrm{M}$ EGCG directly inhibited ubiquitin/proteasome-mediated degradation of the active SREBP2, resulting in an elevated expression of LDLR [155].

\subsubsection{Anthocyanins and Proanthocyanidins}

Anthocyanins are plentiful flavonoid pigments that occur in fruits, vegetables, and other plant-derived foods with a dark color, including blueberries, bilberries, blackcurrants, cranberries, cherries, and black rice [156]. Anthocyanins have been proven to possess antioxidant, anti-inflammatory, anti-atherosclerotic, and antiobesity properties [157-160]. Several epidemiologic studies have reported a marked decrease in LDL-C by the anthocyanin intervention [161-165]. According to previous research, daily supplementation of $90 \mathrm{mg}, 320 \mathrm{mg}$, and $350 \mathrm{mg}$ of purified anthocyanins or extracts could reduce the LDLC level in hyperlipidemic patients by $8 \%, 13 \%$, and $26.3 \%$, respectively. No significant difference was observed in the plasma LDL-C level between patients with nonalcoholic fatty liver disease receiving anthocyanin or the placebo [166]. However, meta-analyses have found a statistically significant reduction of LDL-C in those individuals consuming anthocyanins $[167,168]$. Several mechanisms have been proposed to explain the effect of 
anthocyanins on lowering LDL-C. One possibility is that anthocyanins inhibit the activity of plasma CETP [162]. In a double-blind, randomized, and placebo-controlled trial, Qin and colleagues reported that the intake of $160 \mathrm{mg}$ of anthocyanins twice daily significantly decreased the LDL-C concentration and the activity of CETP [162]. A second possibility is that anthocyanins could reduce the absorption of cholesterol [169]. In a hamster model of diet-induced dyslipidemia, anthocyanins at doses of $0.5 \%$ and $1 \%$ enhanced the fecal excretion of cholesterol accompanied with the downregulation on the gene expression of intestinal NPC1L1, ACAT-2, MTP, and ABCG8 [169]. Studies have consistently found that anthocyanins inhibited the formation of cholesterol micelles and increased the excretion of fecal sterols to lower the plasma LDL-C level [170-172]. The third possibility is that anthocyanin mediate bile acid metabolism [173]. In a study by Wang, it was found that dietary supplementation of $0.06 \%$ cyanidin-3-o- $\beta$-glucoside promoted fecal bile acid excretion and upregulated hepatic CYP7A1 expression compared with the control group [173].

Proanthocyanidins are known as condensed tannins, mainly present in fruits (berries, grapes, and apples), cereals, beans, and beverages (wine and tea) [174]. Proanthocyanidins were reported to consist of catechin, epicatechin, gallocatechin, and epigallocatechin-3gallate, which divided into oligomers and polymers proanthocyanidins in terms of degree of polymerization [175]. Proanthocyanidins are believed to possess antiobesity, antioxidant, anti-inflammatory, anticancer, and hypolipidemic properties $[176,177]$. Previous studies showed that supplementation of proanthocyanidins could reduce both plasma TC and LDL-C levels $[176,178]$. The proanthocyanidins group was administrated with purified proanthocyanidins from lotus (Nelumbo nucifera, Gaertn) seed pot in an aqueous solution through an oral gavage with a dose of $25 \mathrm{mg} / \mathrm{kg} \mathrm{bw}$. Compared with the model group, the LDL-C level in the proanthocyanidins group was reduced by $48 \%(p<0.05)$. The underlying mechanisms for lowering the plasma LDL-C level by proanthocyanidins are as follows. Firstly, proanthocyanidins were involved in the regulation of bile acid metabolism. For example, dietary supplementation of $1 \%$ grape seed proanthocyanidin increased the excretion of fecal bile acids and the upregulation of CYP7A1 in both the transcriptional and translational levels [179]. Similarly, supplementation with a high-cholesterol diet containing $1 \%$ cacao procyanidins could also enhance the fecal bile acid excretion in rats [180]. Heidker pointed out that grape seed procyanidin could not only enhance the expression of CYP7A1 but also decrease the absorption of intestinal bile acid by downregulating ASBT expression [181]. Secondly, the reduction of the plasma LDL-C level by proanthocyanidins $(250 \mathrm{mg} / \mathrm{kg} \mathrm{bw})$ was associated with promoting the excretion of fecal cholesterol. The consumption of proanthocyanidins from cacao could inhibit the intestinal absorption of cholesterol through decreasing micellar cholesterol solubility and enhancing cholesterol excretion [180]. Thirdly, daily administration of $25 \mathrm{mg} / \mathrm{kg}$ bw of grape seed proanthocyanidins in rats had been shown to decrease the LDL-C level by $57 \%$. The underlying mechanism involved disturbing VLDL assembling by repressing the expression of MTP and apoB [182].

\subsubsection{Curcumin}

Curcumin, a hydrophobic polyphenol extracted from turmeric, has been widely used as a dietary spice by many cultures [183]. Curcumin was reported to exhibit broad spectral biological and pharmacologic activities including antioxidant, anti-inflammatory, antidiabetic, hypoglycemic, and antimicrobial capacities [184]. Moreover, curcumin was also shown to possess antihyperlipidemic activity $[185,186]$. Animal studies indicated that curcumin consumption could inhibit the LDL-C level in rats and hamsters fed with a high-fat diet [186-189]. After supplementation with $0.05 \%$ curcumin in male hamsters for 12 weeks, the LDL-C level was decreased by $34 \%$ compared to model group. Moreover, curcumin supplementation at a dose of $80 \mathrm{mg} / \mathrm{kg}$ bw could reduce the LDL-C level by $53 \%$ in obese rats [190]. Several human studies showed that curcumin could significantly decrease the plasma level of LDL-C in healthy middle-aged people and in patients with polycystic ovary syndrome, nonalcoholic fatty liver disease, mild chronic obstructive pulmonary disease, or 
type 2 diabetes [185,191-194]. Daily $180 \mathrm{mg}$ curcumin supplementation in subjects with mild COPD was effective in diminishing the LDL-C level by approximately $11 \%$. The LDL-C level in patients with nonalcoholic fatty liver disease was decreased by $23 \%$ after $1000 \mathrm{mg}$ of curcumin intervention. Supplementation with curcumin decreased intestinal cholesterol absorption and further plasma LDL-C levels by inhibiting the intestinal expression of NPC1L1 [186,195]. Curcumin could also elevate the expression of hepatic LDLR via the sterol regulatory element (SRE) pathway [196,197]. However, Tai proved that a $20 \mu \mathrm{M}$ curcumin treatment enhanced LDL uptake in HepG2 cell by approximately $23 \%$. The mechanism was that curcumin enhanced the density and activity of LDLR through the inhibition of PCSK9 [198]. Tai's results were supported by another study that curcumin could promote LDLR expression by inhibiting the expression of PCSK9 [199]. Moreover, curcumin was found to decrease PCSK9 expression via reducing the nuclear abundance of HNF-1 $\alpha$, an important PCSK9 regulator [198]. Moreover, curcumin regulated the metabolism of LDL by improving the C-to-U RNA edition of apoB, which is major component of LDL [200]. A total of $0.1 \%$ curcumin consumption could also stimulate the conversion of hepatic cholesterol to bile acids via the upregulation of CYP7A1, and by further promoting the removal of LDL (about 56\%) [188].

\subsubsection{Isoflavone}

Genistein, a principal bioactive soy isoflavone, has received great attention due to antioxidative, anti-inflammatory and lipid-lowering effects [201,202]. There exists a considerable amount of evidence supporting the role of genistein in the prevention of cardiovascular disease, osteoporosis, diabetes, and hyperlipemia [203-205]. Growing experimental data has showed that genistein consumption made a reduction in LDL-C levels [206-209]. Genistein supplementation at a dose of $2 \mathrm{~g} / \mathrm{kg}$ bw significantly reduced the LDL-C level by $40 \%$ in high-fat-diet-fed hamsters. In a randomized, double-blind, and placebo-controlled trial, $54 \mathrm{mg}$ of genistein daily for one year were found to decrease the LDL-C level (mean from 108.8 to $78.7 \mathrm{mg} / \mathrm{dL}$ ) in Caucasian postmenopausal subjects with metabolic syndrome [210]. Similarly, a meta-analysis found that genistein consumption could significantly decrease the LDL-C level in postmenopausal women with metabolic syndrome [211]. Several mechanisms have been proposed to explain the effect of genistein on decreasing the LDL-C level. Genistein could upregulate the expression of hepatic LDLR, thereby inducing the clearance of LDL-C [207]. This result was also verified in vitro studies [212,213]. Moreover, Kartawijaya supported that $40 \mu \mathrm{M}$ genistein treatment could activate the JNK signaling pathway and SREBP2 processing, which was followed by the upregulation of LDLR [213]. Genistein could also interfere with VLDL assembly. Borradaile found that $50 \mu \mathrm{M}$ genistein could decrease the secretion of apoB through multiple mechanisms, including inhibiting the expression of HMGR, the activity of ACAT, and the expression and activity of MTP [214].

\subsection{Stilbenes}

Resveratrol is a polyphenolic compound produced by grapes, peanuts, vegetables and other plant species [215]. Polydatin, as the glycoside of resveratrol, is the main bioactive constituent of Polygonum cuspidatum Sieb. et Zucc [216]. Studies have demonstrated that resveratrol and its glycoside exhibit a lipid-lowering effect $[217,218]$. Daily supplementation with $0.02 \%$ resveratrol in apoE-deficient mice had been shown to decrease the LDL-C content by $15 \%$. The level of LDL-C was evidently decreased after 3 weeks of treatment with polydatin $(25,50$, and $100 \mathrm{mg} / \mathrm{kg}$ bw) by $27 \%, 30 \%$, and $33 \%$, respectively [219]. The underlying mechanisms by which resveratrol and its glycoside mitigate the LDL-C level have been investigated in cell cultures and in animals. Principally, resveratrol and its glycoside increased the expression and activity of hepatic LDLR [220]. Evidence indicated that a high-fat diet plus resveratrol ( 50 and $100 \mathrm{mg} / \mathrm{kg} \mathrm{bw}$ ) could downregulate the expression of LDLR in rats and further reduce the level of LDL-C [220]. Resveratrol regulated the expression of LDLR via two ways. On the one hand, a $50 \mu \mathrm{M}$ resveratrol treatment enhanced LDLR transcription via the proteolytic activation of SREBPs and exhib- 
ited a 59\% increase in the LDL uptake [221]. On the other hand, both $10 \mu \mathrm{M}$ and $20 \mu \mathrm{M}$ resveratrol downregulated PCSK9 expression to maintain LDLR levels on the surface of cells [222]. Similarly, $20 \mu \mathrm{M}$ polydatin upregulated the protein expression level of LDLR and inhibited PCSK9 protein expression, as well as the combination between PCSK9 and LDLR [223]. To a lesser extent, resveratrol also involved bile acid metabolism. Chaothe and Swaan found that resveratrol promoted bile acid transporter ASBT degradation via the ubiquitin-proteasome pathway, which might be associated with an increase in fecal bile acid excretion [224,225]. Shao and colleagues found resveratrol and its liver metabolite resveratrol glucuronide at a dose of $25 \mu \mathrm{M}$ caused a significant increase in hepatic CYP7A1 and BSEP, indicating the increase in the synthesis and efflux of bile acids [56].

\subsection{Effect of Other Polyphenols on Lowering LDL-C and Mode of Action}

In addition to the above mentioned, polyphenols which exerted LDL-C lowering effects also included protocatechuic acid, vanillic acid, puerarin, kaempferol, and so on. Herein, we focus on the mechanisms by which other dietary polyphenols alleviated the LDL-C level. In vivo study reported that vanillic acid possessed LDL-C lowering potential by inhibiting the HMGR activity [226]. Vanillic acid was orally given ( $50 \mathrm{mg} / \mathrm{kg} \mathrm{bw})$ to hypertensive rats for 4 weeks. The results revealed that vanillic acid reduced the plasma LDL-C level by $64 \%$ and inhibited HMGR activity (Table 4). Moreover, an animal study conducted by Ma et al. revealed that the decrease of the plasma LDL-C concentration in the puerarin intervention group was associated with the induction of CYP7A1 [227]. In another study, naringin $(25 \mathrm{mg} / \mathrm{kg}$ bw) could reduce the plasma LDL-C level in obese mice via inhibiting the expression of SREBP2 and PCSK9 and inducing the expression of LDLR [228]. Kubota and colleagues elucidated the underlying mechanism of lowering LDL-C by ellagic acid [229]. In the presence of $25 \mu \mathrm{M}$ ellagic acid, the expression of LDLR was significantly increased while extracellular apoB protein and MTP mRNA levels were decreased $(p<$ 0.05 ) (Table 5). Another in vitro study conducted by Ochaiai et al. reported that the uptake of fluorescent-labeled LDL in HepG2 cells was increased after treatment with $100 \mu \mathrm{M}$ kaempferol for $24 \mathrm{~h}$ [230]. The results were attributed to the promotion of LDLR expression and activity in the presence of kaempferol. Moreover, luteolin could affect the cholesterol absorption by regulating the expression of NPC1L1 in Caco-2 cells [136]. Tables 4 and 5 respectively summarizes the results and details of the listed references based on in vitro or in vivo models.

Table 4. Effect of other polyphenols on LDL-C and their mechanism based on in vivo models.

\begin{tabular}{|c|c|c|c|c|c|}
\hline Subclasses & Polyphenol & Study Type & Results & Mechanism & References \\
\hline Phenolic acid & $\begin{array}{l}\text { Protocatechuic } \\
\text { acid }\end{array}$ & $\begin{array}{l}0.05 \%(w / w) \text { given } \\
\text { to cholesterol-fed } \\
\text { rats for } 4 \text { weeks }\end{array}$ & $\begin{array}{c}\text { Lowers levels of } \\
\text { non-HDL-C from } \\
0.88 \pm 014 \\
\text { mmol/L to } 0.74 \pm \\
0.04 \mathrm{mmol} / \mathrm{L} \\
\quad(p<0.05)\end{array}$ & $\begin{array}{c}\text { Increases the expression of } \\
\text { hepatic LDLR }\end{array}$ & [231] \\
\hline Phenolic acid & Vanillic acid & $\begin{array}{l}\text { Vanillic acid } \\
(50 \mathrm{mg} / \mathrm{kg} \text { bw }) \text { to } \\
\text { hypertensive rats } \\
\text { for } 4 \text { weeks }\end{array}$ & $\begin{array}{l}\text { Decreases in } \\
\text { plasma LDL-C by } \\
64 \%(p<0.05)\end{array}$ & Inhibits HMGR activity & [226] \\
\hline Isoflavone & $\begin{array}{l}\text { Puerarin } \\
\text { glycosides }\end{array}$ & $\begin{array}{c}\text { Puerarin } \\
\text { glycosides }(0.1 \%) \\
\text { was given to mice } \\
\text { for } 3 \text { weeks }\end{array}$ & $\begin{array}{l}\text { Reduction in } \\
\text { plasma TC levels } \\
\qquad(p<0.05)\end{array}$ & $\begin{array}{l}\text { Increases the expression of } \\
\text { LDLR; Downregulates the } \\
\text { transcription and } \\
\text { translation of HMGR }\end{array}$ & [232] \\
\hline Isoflavone & Puerarin & $\begin{array}{c}\text { Orally }(200 \mathrm{mg} / \mathrm{kg} \\
\text { bw and } 400 \mathrm{mg} / \mathrm{kg} \\
\text { bw) puerarin } \\
\text { administered to } \\
\text { hyperlipidaemia } \\
\text { mice for } 8 \text { weeks }\end{array}$ & $\begin{array}{l}\text { Decreases in } \\
\text { plasma LDL-C } \\
\text { level }(p<0.05)\end{array}$ & $\begin{array}{c}\text { Regulates the expression } \\
\text { of phosphorylated JNK, } \\
\text { phosphorylated c-Jun } \\
\text { protein, and CYP7A1 }\end{array}$ & [227] \\
\hline
\end{tabular}


Table 4. Cont.

\begin{tabular}{|c|c|c|c|c|c|}
\hline Subclasses & Polyphenol & Study Type & Results & Mechanism & References \\
\hline Flavones & Apigenin & $\begin{array}{l}\text { Apigenin was } \\
\text { orally } \\
\text { administrated to } \\
\text { high-fat-fed mice }\end{array}$ & $\begin{array}{l}\text { Decreases the level } \\
\text { of LDL-C in } \\
\text { plasma by } 19 \%, \\
16 \% \text {, and } 55 \%, \\
\text { respectively } \\
(p<0.05)\end{array}$ & $\begin{array}{l}\text { Promotes the absorption } \\
\text { of hepatic LDL-C and } \\
\text { increases the } \\
\text { transformation of hepatic } \\
\text { cholesterol into bile acid } \\
\text { by regulating LDLR and } \\
\text { CYP7A1 expression }\end{array}$ & [233] \\
\hline Flavones & Apigenin & $\begin{array}{l}\text { Apigenin }(60 \mathrm{ppm} \\
\text { and } 300 \mathrm{ppm}) \\
\text { given orally to } \\
\text { hamsters with } \\
\text { hypercholestero- } \\
\text { laemia }\end{array}$ & $\begin{array}{c}\text { Reduces the } \\
\text { nonHDL-C level } \\
\text { by } 40 \% \text { and } 41 \% \\
(p<0.05)\end{array}$ & $\begin{array}{l}\text { Reduces the uptake of } \\
\text { dietary cholesterol by } \\
\text { inhibiting NPC1L1; } \\
\text { Stimulates hepatic } \\
\text { LDLR expression }\end{array}$ & [234] \\
\hline Flavones & Luteolin & $\begin{array}{c}\text { Mice were } \\
\text { administered daily } \\
50 \mathrm{mg} / \mathrm{kg} \text { bw of } \\
\text { luteolin in addition } \\
\text { to ethanol } \\
\text { exposure }\end{array}$ & $\begin{array}{l}\text { Reduces LDL-C } \\
\text { level in plasma by } \\
52 \%(p<0.05)\end{array}$ & $\begin{array}{l}\text { Inhibits cholesterol } \\
\text { biosynthesis by regulating } \\
\text { SREBP2 and HMGR }\end{array}$ & [235] \\
\hline Flavones & Luteolin & $\begin{array}{l}\text { Luteolin }(1.5 \%) \\
\text { was given to } \\
\text { high-fat-fed mice } \\
\text { for } 57 \text { days }\end{array}$ & $\begin{array}{c}\text { Reduces LDL-C } \\
\text { levels by } 33 \%(p< \\
0.05)\end{array}$ & $\begin{array}{c}\text { Suppresses HNF4 } \alpha \\
\text { targeted genes, such as } \\
\text { MTP, apoB }\end{array}$ & [236] \\
\hline Flavones & Luteolin & $\begin{array}{l}\text { Luteolin } \\
\text { (50 mg/kg bw) } \\
\text { given orally to } \\
\text { hyperlipidemia } \\
\text { rats for } 6 \text { weeks }\end{array}$ & $\begin{array}{l}\text { Reduces LDL-C } \\
\text { levels by } 34 \% \\
\quad(p<0.05)\end{array}$ & $\begin{array}{l}\text { Increases CYP7A1 } \\
\text { activities in liver }\end{array}$ & [81] \\
\hline Flavones & $\begin{array}{l}\text { Luteolin-7- } \\
\text { glucoside }\end{array}$ & $\begin{array}{l}\text { Luteolin-7- } \\
\text { glucoside } \\
(2 \mathrm{mg} / \mathrm{kg} \mathrm{bw}) \\
\text { orally to rats }\end{array}$ & $\begin{array}{l}\text { Decreases levels of } \\
\text { LDL-C in plasma } \\
\text { by } 40 \%(p<0.05)\end{array}$ & $\begin{array}{l}\text { Decreases cholesterol } \\
\text { synthesis via decreasing } \\
\text { HMGR expression }\end{array}$ & [237] \\
\hline Flavanones & Naringin & $\begin{array}{c}\text { Naringin } \\
(25 \mathrm{mg} / \mathrm{kg} \mathrm{bw}) \\
\text { given orally to } \\
\text { obese mice for } 8 \\
\text { weeks }\end{array}$ & $\begin{array}{l}\text { Decreases the level } \\
\text { of LDL-C in } \\
\text { plasma }(p<0.05)\end{array}$ & $\begin{array}{l}\text { Downregulates the } \\
\text { expression of SREBP2 and } \\
\text { PCSK9, and upregulates } \\
\text { the expression of LDLR } \\
\text { through AMPK activation }\end{array}$ & [228] \\
\hline Ligans & Leoligin & $\begin{array}{c}0.14 \mathrm{mg} \text { leoligin } \\
\text { was given to CETP } \\
\text { transgenic mice for } \\
7 \text { days }\end{array}$ & $\begin{array}{l}\text { Reduces LDL-C } \\
\text { level in plasma }\end{array}$ & Activates CETP activity & [238] \\
\hline Ligans & Sesamin & $\begin{array}{l}\text { Hamsters were fed } \\
\text { two experimental } \\
\text { diets containing } \\
0.02 \% \text { sesamin or } \\
0.5 \% \text { sesamin for } \\
6 \text { weeks }\end{array}$ & $\begin{array}{l}\text { Lowers plasma } \\
\text { non-HDL-C level } \\
\text { by } 25 \% \text { and } 32 \% \\
\quad(p<0.05)\end{array}$ & $\begin{array}{l}\text { Reduces cholesterol } \\
\text { absorption by inhibiting } \\
\text { intestinal NPC1L1, } \\
\text { ACAT2, MTP, and } \\
\text { ABCG5/8; Stimulates } \\
\text { LDLR and CYP7A1 } \\
\text { expression }\end{array}$ & [239] \\
\hline
\end{tabular}


Table 5. Effect of other polyphenols on LDL-C and their mechanism based on in vitro models.

\begin{tabular}{|c|c|c|c|c|c|}
\hline Subclasses & Polyphenol & Study Type & Results & Mechanism & References \\
\hline Phenolic acid & Ellagic acid & $\begin{array}{l}25 \mu \mathrm{M} \text { ellagic acid } \\
\text { to HepG2 cells }\end{array}$ & $\begin{array}{l}\text { Regulates } \\
\text { cholesterol } \\
\text { metabolism }\end{array}$ & $\begin{array}{c}\text { Upregulates of LDLR, } \\
\text { downregulates MTP } \\
\text { mRNA and } \\
\text { extracellular } \\
\text { apoB levels }\end{array}$ & [229] \\
\hline Flavonols & Kaempferol & $\begin{array}{l}\text { The HepG2 cells } \\
\text { were incubated for } \\
24 \mathrm{~h} \text { with } \\
\text { kaempferol } \\
(100 \mu \mathrm{M})\end{array}$ & $\begin{array}{c}\text { Increases } \\
\text { fluorescent- } \\
\text { labeled LDL } \\
\text { uptake }(p<0.05)\end{array}$ & $\begin{array}{l}\text { Stimulates the } \\
\text { expression of LDLR } \\
\text { through activating } \\
\text { LDLR transcription } \\
\text { factor Sp1 }\end{array}$ & [230] \\
\hline Flavones & Luteolin & $\begin{array}{l}\text { Caco- } 2 \text { cells were } \\
\text { incubated with } \\
100 \mu \mathrm{M} \text { luteolin }\end{array}$ & $\begin{array}{l}\text { Inhibits cholesterol } \\
\text { uptake in Caco-2 } \\
\text { cells }(p<0.05)\end{array}$ & $\begin{array}{c}\text { Inhibits intestinal } \\
\text { cholesterol absorption } \\
\text { mediated by NPC1L1 }\end{array}$ & [136] \\
\hline Flavones & Rutin & $\begin{array}{l}\text { Caco- } 2 \text { cells were } \\
\text { treated with } \\
115.7 \mu \mathrm{M} \text { rutin; } \\
\text { Rutin }(17.85 \mu \mathrm{M}) \\
\text { was used to } \\
\text { measure HMGR } \\
\text { activity inhibition }\end{array}$ & $\begin{array}{l}\text { Lowers the } \\
\text { amount of } \\
\text { cholesterol in the } \\
\text { intracellular } \\
\text { compartment; } \\
\text { Reduces HMGR } \\
\text { activity by } 50 \% \\
(p<0.05)\end{array}$ & $\begin{array}{l}\text { Inhibits the uptake of } \\
\text { dietary cholesterol and } \\
\text { the activity of HMGR }\end{array}$ & [240] \\
\hline Flavanones & Hesperetin & $\begin{array}{l}\text { HepG2 cells were } \\
\text { exposed to } \\
\text { hesperetin } \\
(100 \mu \mathrm{M})\end{array}$ & $\begin{array}{c}\text { Induces the } \\
\text { activity of LDLR } \\
\text { promoter }(p<0.05)\end{array}$ & $\begin{array}{c}\text { Induces the } \\
\text { transcription of LDLR } \\
\text { through SREBPs }\end{array}$ & [241] \\
\hline Flavanones & $\begin{array}{l}\text { Glucosyl } \\
\text { hesperidin }\end{array}$ & $\begin{array}{l}\text { HepG2 cells were } \\
\text { treated with } 0.8 \\
\mathrm{mM} \text { and } 1.2 \mathrm{mM} \\
\text { glucosyl } \\
\text { hesperidin }\end{array}$ & $\begin{array}{l}\text { Reduces cellular } \\
\text { cholesteryl ester } \\
\text { content }(p<0.05)\end{array}$ & $\begin{array}{l}\text { Suppresses the } \\
\text { secretion of apoB }\end{array}$ & [242] \\
\hline
\end{tabular}

\section{Limitations and Suggestions}

From the above studies, dietary polyphenols have exhibited the potential effect on lowering the level of LDL-C. However, there are many limitations, which are as follows:

1. In some studies, the crude extracts from food origin were applied to study the LDL-Creducing activities without determining the active ingredients;

2. In most previous studies, researchers only focused on a partial mechanism about a particular polyphenol without conducting a comprehensive study involved in polyphenol's potential regulatory pathways;

3. Bioactivity investigations using cell lines have made an extensive use of polyphenols at concentrations in the low- $\mu \mathrm{M}$-to-mM range. However, after ingestion the dietary polyphenols appear in the circulatory system as phase II metabolites, and their presence in plasma rarely exceeds nM concentrations [12]. There is lack of data which explores the effect of polyphenols metabolites on lowering LDL-C;

4. Researchers paid more attention to in vitro and animal studies but less attention to clinal studies.

Thus, further studies are required to separate and identify the active components in the presence of crude extracts. Moreover, all the potential regulatory pathways about inhibiting the LDL-C level should be adequately considered during research. Furthermore, a comparative study of the effect of polyphenols and their metabolites on lowering LDL-C is needed. Finally, we should focus on clinal studies to provide a necessary dietary reference for people. 


\section{Conclusions}

LDL-C-causing CVDs were repeatedly demonstrated in different experimental studies. LDL-C lowering therapies have become a preferred target for CVDs resulting from liner relationship between LDL-C and CVDs risk. LDL-C lowering therapies were mainly involved in hepatic and intestinal target organs. In hepatocytes, the molecular targets contained HMGR, LDLR, PCSK9, IDOL, MTP, apoB, CYP7A1, CETP, SREBPs, squalene synthase, and ACLY, while ABCG5/8, NPC1L1, MTP, ACAT, and ASBT were believed to be associated with the absorption and excretion of cholesterol and bile acid in the gut. From the above studies, dietary polyphenols have exhibited a potential effect on lowering the level of LDL-C via various molecular targets. However, further deep studies are required to elucidate how polyphenols interact with the targets.

Author Contributions: Conceptualization, B.J. and F.Z.; writing—original draft preparation, P.S.; writing—review and editing, L.Z. (Liang Zhao) and N.Z.; visualization, J.Z.; supervision, L.Z. (Liebing Zhang) and W.W.; project administration, F.Z.; funding acquisition, L.Z. (Liang Zhao) All authors have read and agreed to the published version of the manuscript.

Funding: This research was funded by the China Postdoctoral Science Foundation, grant number 2019TQ0011 to L.Z. (Liang Zhao).

Acknowledgments: We are grateful to the study participants.

Conflicts of Interest: The authors declare no conflict of interest.

\section{References}

1. Şahin, B.; İlgün, G. Risk factors of deaths related to cardiovascular diseases in World Health Organization (WHO) member countries. Health Soc. Care Community 2020. [CrossRef] [PubMed]

2. McLaren, J.E.; Michael, D.R.; Ashlin, T.G.; Ramji, D.P. Cytokines, macrophage lipid metabolism and foam cells: Implications for cardiovascular disease therapy. Prog. Lipid Res. 2011, 50, 331-347. [CrossRef] [PubMed]

3. Hung, J.; Miscianinov, V.; Sluimer, J.C.; Newby, D.E.; Baker, A.H. Targeting non-coding RNA in vascular biology and disease. Front. Physiol. 2018, 9, 1655. [CrossRef] [PubMed]

4. Ference, B.A.; Mahajan, N. The role of early LDL lowering to prevent the onset of atherosclerotic disease. Curr. Atheroscler. Rep. 2013, 15, 312. [CrossRef]

5. Pirillo, A.; Catapano, A.L.; Norata, G.D. Recent insights into low-density lipoprotein metabolism and therapy. Curr. Opin. Clin. Nutr. Metab. Care 2021, 24, 120-126. [CrossRef]

6. Gitt, A.K.; Drexel, H.; Feely, J.; Ferrières, J.; Gonzalez-Juanatey, J.R.; Thomsen, K.K.; Leiter, L.A.; Lundman, P.; da Silva, P.M.; Pedersen, T. Persistent lipid abnormalities in statin-treated patients and predictors of LDL-cholesterol goal achievement in clinical practice in Europe and Canada. Eur. J. Prev. Cardiol. 2012, 19, 221-230. [CrossRef]

7. Ravn-Haren, G.; Dragsted, L.O.; Buch-Andersen, T.; Jensen, E.N.; Jensen, R.I.; Németh-Balogh, M.; Paulovicsová, B.; Bergström, A.; Wilcks, A.; Licht, T.R. Intake of whole apples or clear apple juice has contrasting effects on plasma lipids in healthy volunteers. Eur. J. Nutr. 2013, 52, 1875-1889. [CrossRef]

8. Brader, L.; Overgaard, A.; Christensen, L.P.; Jeppesen, P.B.; Hermansen, K. Polyphenol-rich bilberry ameliorates total cholesterol and LDL-cholesterol when implemented in the diet of Zucker diabetic fatty rats. Rev. Diabet. Stud. 2013, 10, 270. [CrossRef]

9. Kardum, N.; Milovanović, B.; Šavikin, K.; Zdunić, G.; Mutavdžin, S.; Gligorijević, T.; Spasić, S. Beneficial effects of polyphenol-rich chokeberry juice consumption on blood pressure level and lipid status in hypertensive subjects. J. Med. Food 2015, 18, 1231-1238. [CrossRef]

10. Zhou, Y.; Zheng, J.; Li, Y.; Xu, D.P.; Li, S.; Chen, Y.M.; Li, H.B. Natural Polyphenols for Prevention and Treatment of Cancer. Nutrients 2016, 8, 515. [CrossRef]

11. Chambers, K.F.; Day, P.E.; Aboufarrag, H.T.; Kroon, P.A. Polyphenol effects on cholesterol metabolism via bile acid biosynthesis, CYP7A1: A review. Nutrients 2019, 11, 2588. [CrossRef]

12. Del Rio, D.; Rodriguez-Mateos, A.; Spencer, J.P.; Tognolini, M.; Borges, G.; Crozier, A. Dietary (poly) phenolics in human health: Structures, bioavailability, and evidence of protective effects against chronic diseases. Antioxid. Redox Signal. 2013, 18, 1818-1892. [CrossRef]

13. Xiao, J.; Hogger, P. Dietary polyphenols and type 2 diabetes: Current insights and future perspectives. Curr. Med. Chem. 2015, 22, 23-38. [CrossRef]

14. Shen, C.-L.; Smith, B.J.; Lo, D.-F.; Chyu, M.-C.; Dunn, D.M.; Chen, C.-H.; Kwun, I.-S. Dietary polyphenols and mechanisms of osteoarthritis. J. Nutr. Biochem. 2012, 23, 1367-1377. [CrossRef]

15. Wang, S.; Moustaid-Moussa, N.; Chen, L.; Mo, H.; Shastri, A.; Su, R.; Bapat, P.; Kwun, I.; Shen, C.-L. Novel insights of dietary polyphenols and obesity. J. Nutr. Biochem. 2014, 25, 1-18. [CrossRef] 
16. Chen, G.; Wang, H.; Zhang, X.; Yang, S.-T. Nutraceuticals and functional foods in the management of hyperlipidemia. Crit. Rev. Food Sci. Nutr. 2014, 54, 1180-1201. [CrossRef]

17. Mehmood, A.; Zhao, L.; Wang, C.; Nadeem, M.; Raza, A.; Ali, N.; Shah, A.A. Management of hyperuricemia through dietary polyphenols as a natural medicament: A comprehensive review. Crit. Rev. Food Sci. Nutr. 2019, 59, 1433-1455. [CrossRef]

18. Wang, O.; Liu, J.; Cheng, Q.; Guo, X.; Wang, Y.; Zhao, L.; Zhou, F.; Ji, B. Effects of Ferulic Acid and gamma-Oryzanol on High-Fat and High-Fructose Diet-Induced Metabolic Syndrome in Rats. PLoS ONE 2015, 10, e0118135. [CrossRef]

19. Zhang, J.; Zhao, L.; Cheng, Q.; Ji, B.; Yang, M.; Sanidad, K.Z.; Wang, C.; Zhou, F. Structurally Different Flavonoid Subclasses Attenuate High-Fat and High-Fructose Diet Induced Metabolic Syndrome in Rats. J. Agric. Food Chem. 2018, 66, 12412-12420. [CrossRef]

20. Zhao, L.; Wang, Y.; Liu, J.; Wang, K.; Guo, X.; Ji, B.; Wu, W.; Zhou, F. Protective Effects of Genistein and Puerarin against Chronic Alcohol-Induced Liver Injury in Mice via Antioxidant, Antiinflammatory, and Anti-apoptotic Mechanisms (vol 64, pg 7291, 2016). J. Agric. Food Chem. 2016, 64, 8463. [CrossRef]

21. Zhao, L.; Zhang, N.; Yang, D.; Yang, M.; Guo, X.; He, J.; Wu, W.; Ji, B.; Cheng, Q.; Zhou, F. Protective Effects of Five Structurally Diverse Flavonoid Subgroups against Chronic Alcohol-Induced Hepatic Damage in a Mouse Model. Nutrients 2018, 10, 1754. [CrossRef] [PubMed]

22. Atici, E.B.; Karlığa, B. Identification, synthesis and characterization of process related desfluoro impurity of ezetimibe and HPLC method validations. J. Pharm. Anal. 2015, 5, 356-370. [CrossRef] [PubMed]

23. Nemes, K.; Åberg, F.; Gylling, H.; Isoniemi, H. Cholesterol metabolism in cholestatic liver disease and liver transplantation: From molecular mechanisms to clinical implications. World J. Hepatol. 2016, 8, 924. [CrossRef] [PubMed]

24. Bruckert, E.; Giral, P.; Tellier, P. Perspectives in cholesterol-lowering therapy: The role of ezetimibe, a new selective inhibitor of intestinal cholesterol absorption. Circulation 2003, 107, 3124-3128. [CrossRef]

25. Wei, J.; Fu, Z.-Y.; Li, P.-S.; Miao, H.-H.; Li, B.-L.; Ma, Y.-T.; Song, B.-L. The clathrin adaptor proteins ARH, Dab2, and numb play distinct roles in Niemann-Pick C1-Like 1 versus low density lipoprotein receptor-mediated cholesterol uptake. J. Biol. Chem. 2014, 289, 33689-33700. [CrossRef]

26. Nguyen, T.M.; Sawyer, J.K.; Kelley, K.L.; Davis, M.A.; Rudel, L.L. Cholesterol esterification by ACAT2 is essential for efficient intestinal cholesterol absorption: Evidence from thoracic lymph duct cannulation. J. Lipid Res. 2012, 53, 95-104. [CrossRef]

27. Wang, D.Q.-H. Regulation of intestinal cholesterol absorption. Annu. Rev. Physiol. 2007, 69, 221-248. [CrossRef]

28. Visser, M.E.; Jakulj, L.; Kastelein, J.J.; Stroes, E.S. LDL-C-lowering therapy: Current and future therapeutic targets. Curr. Cardiol. Rep. 2008, 10, 512. [CrossRef]

29. Mensenkamp, A.R.; Van Luyn, M.J.; Havinga, R.; Teusink, B.; Waterman, I.J.; Mann, C.J.; Elzinga, B.M.; Verkade, H.J.; Zammit, V.A.; Havekes, L.M. The transport of triglycerides through the secretory pathway of hepatocytes is impaired in apolipoprotein $\mathrm{E}$ deficient mice. J. Hepatol. 2004, 40, 599-606. [CrossRef]

30. Tiwari, S.; Siddiqi, S.A. Intracellular trafficking and secretion of VLDL. Arterioscler. Thromb. Vasc. Biol. 2012, 32, 1079-1086. [CrossRef]

31. Feingold, K.R.; Grunfeld, C. Introduction to Lipids and Lipoproteins; MDText.com, Inc.: South Dartmouth, MA, USA, 2021.

32. Dietschy, J.M.; Turley, S.D.; Spady, D.K. Role of liver in the maintenance of cholesterol and low density lipoprotein homeostasis in different animal species, including humans. J. Lipid Res. 1993, 34, 1637-1659. [CrossRef]

33. Cedó, L.; Farràs, M.; Lee-Rueckert, M. Molecular insights into the mechanisms underlying the cholesterol-lowering effects of phytosterols. Curr. Med. Chem. 2019, 26, 6704-6723. [CrossRef]

34. Olofsson, S.O.; Boren, J. Apolipoprotein B: A clinically important apolipoprotein which assembles atherogenic lipoproteins and promotes the development of atherosclerosis. J. Intern. Med. 2005, 258, 395-410. [CrossRef]

35. Boren, J.; Wettesten, M.; Sjöberg, A.; Thorlin, T.; Bondjers, G.; Wiklund, O.; Olofsson, S. The assembly and secretion of apoB 100 containing lipoproteins in Hep G2 cells. Evidence for different sites for protein synthesis and lipoprotein assembly. J. Biol. Chem. 1990, 265, 10556-10564. [CrossRef]

36. Lagrost, L. Plasma phospholipid transfer protein: A multifaceted protein with a key role in the assembly and secretion of apolipoprotein B-containing lipoproteins by the liver. Hepatology 2012, 56, 415-418. [CrossRef]

37. Manchekar, M.; Liu, Y.; Sun, Z.; Richardson, P.E.; Dashti, N. Phospholipid transfer protein plays a major role in the initiation of apolipoprotein B-containing lipoprotein assembly in mouse primary hepatocytes. J. Biol. Chem. 2015, 290, 8196-8205. [CrossRef]

38. Ye, J.; Li, J.Z.; Liu, Y.; Li, X.; Yang, T.; Ma, X.; Li, Q.; Yao, Z.; Li, P. Cideb, an ER-and lipid droplet-associated protein, mediates VLDL lipidation and maturation by interacting with apolipoprotein B. Cell Metab. 2009, 9, 177-190. [CrossRef]

39. Hossain, T.; Riad, A.; Siddiqi, S.; Parthasarathy, S.; Siddiqi, S.A. Mature VLDL triggers the biogenesis of a distinct vesicle from the trans-Golgi network for its export to the plasma membrane. Biochem. J. 2014, 459, 47-58. [CrossRef]

40. Masson, W.; Lobo, M.; Siniawski, D.; Huerín, M.; Molinero, G.; Valero, R.; Nogueira, J.P. Therapy with cholesteryl ester transfer protein (CETP) inhibitors and diabetes risk. Diabetes Metab. 2018, 44, 508-513. [CrossRef]

41. Barter, P.J.; Brewer, H.B., Jr.; Chapman, M.J.; Hennekens, C.H.; Rader, D.J.; Tall, A.R. Cholesteryl ester transfer protein: A novel target for raising HDL and inhibiting atherosclerosis. Arterioscler. Thromb. Vasc. Biol. 2003, 23, 160-167. [CrossRef]

42. Shrestha, S.; Wu, B.J.; Guiney, L.; Barter, P.J.; Rye, K.-A. Cholesteryl ester transfer protein and its inhibitors. J. Lipid Res. 2018, 59, 772-783. [CrossRef]

43. Brown, M.S.; Goldstein, J.L. A receptor-mediated pathway for cholesterol homeostasis. Science 1986, 232, 34-47. [CrossRef] 
44. Esser, V.; Limbird, L.; Brown, M.S.; Goldstein, J.L.; Russell, D.W. Mutational analysis of the ligand binding domain of the low density lipoprotein receptor. J. Biol. Chem. 1988, 263, 13282-13290. [CrossRef]

45. Maxfield, F.R.; McGraw, T.E. Endocytic recycling. Nat. Rev. Mol. Cell Biol. 2004, 5, 121-132. [CrossRef]

46. Goldstein, J.L.; Brown, M.S. The LDL receptor. Arterioscler. Thromb. Vasc. Biol. 2009, 29, 431-438. [CrossRef]

47. Scotti, E.; Calamai, M.; Goulbourne, C.N.; Zhang, L.; Hong, C.; Lin, R.R.; Choi, J.; Pilch, P.F.; Fong, L.G.; Zou, P. IDOL stimulates clathrin-independent endocytosis and multivesicular body-mediated lysosomal degradation of the low-density lipoprotein receptor. Mol. Cell. Biochem. 2013, 33, 1503-1514. [CrossRef]

48. Poirier, S.; Mayer, G.; Poupon, V.; McPherson, P.S.; Desjardins, R.; Ly, K.; Asselin, M.-C.; Day, R.; Duclos, F.J.; Witmer, M. Dissection of the endogenous cellular pathways of PCSK9-induced low density lipoprotein receptor degradation: Evidence for an intracellular route. J. Biol. Chem. 2009, 284, 28856-28864. [CrossRef]

49. Donkers, J.M.; Abbing, R.L.R.; Van de Graaf, S.F. Developments in bile salt based therapies: A critical overview. Biochem. Pharmacol. 2019, 161, 1-13. [CrossRef]

50. Russell, D.W. Fifty years of advances in bile acid synthesis and metabolism. J. Lipid Res. 2009, 50, S120-S125. [CrossRef] [PubMed]

51. Hayashi, H.; Takada, T.; Suzuki, H.; Onuki, R.; Hofmann, A.F.; Sugiyama, Y. Transport by vesicles of glycine-and taurineconjugated bile salts and taurolithocholate 3-sulfate: A comparison of human BSEP with rat Bsep. Biochim. Biophys. Acta Mol. Cell Biol. Lipids 2005, 1738, 54-62. [CrossRef] [PubMed]

52. Dawson, P.A.; Lan, T.; Rao, A. Bile acid transporters. J. Lipid Res. 2009, 50, 2340-2357. [CrossRef] [PubMed]

53. Dawson, P.A.; Hubbert, M.L.; Rao, A. Getting the mOST from OST: Role of organic solute transporter, OST $\alpha$-OST $\beta$, in bile acid and steroid metabolism. Biochim. Biophys. Acta Mol. Cell Biol. Lipids 2010, 1801, 994-1004. [CrossRef] [PubMed]

54. Slijepcevic, D.; Roscam Abbing, R.L.; Katafuchi, T.; Blank, A.; Donkers, J.M.; van Hoppe, S.; de Waart, D.R.; Tolenaars, D.; van der Meer, J.H.; Wildenberg, M. Hepatic uptake of conjugated bile acids is mediated by both sodium taurocholate cotransporting polypeptide and organic anion transporting polypeptides and modulated by intestinal sensing of plasma bile acid levels in mice. Hepatology 2017, 66, 1631-1643. [CrossRef] [PubMed]

55. JG Marin, J.; IR Macias, R.; Briz, O.; M Banales, J.; J Monte, M. Bile acids in physiology, pathology and pharmacology. Curr. Drug Metab. 2016, 17, 4-29. [CrossRef]

56. Shao, D.; Wang, Y.; Huang, Q.; Shi, J.; Yang, H.; Pan, Z.; Jin, M.; Zhao, H.; Xu, X. Cholesterol-Lowering Effects and Mechanisms in View of Bile Acid Pathway of Resveratrol and Resveratrol Glucuronides. J. Food Sci. 2016, 81, H2841-H2848. [CrossRef]

57. Huff, M.W.; Telford, D.E.; Edwards, J.Y.; Burnett, J.R.; Barrett, P.H.R.; Rapp, S.R.; Napawan, N.; Keller, B.T. Inhibition of the apical sodium-dependent bile acid transporter reduces LDL cholesterol and apoB by enhanced plasma clearance of LDL apoB. Arterioscler. Thromb. Vasc. Biol. 2002, 22, 1884-1891. [CrossRef]

58. Al-Dury, S.; Marschall, H.-U. Ileal bile acid transporter inhibition for the treatment of chronic constipation, cholestatic pruritus, and NASH. Front. Pharmacol. 2018, 9, 931. [CrossRef]

59. Feingold, K.R.J.E. Cholesterol Lowering Drugs; MDText.com, Inc.: South Dartmouth, MA, USA, 2021.

60. Clerc, R.G.; Stauffer, A.; Weibel, F.; Hainaut, E.; Perez, A.; Hoflack, J.-C.; Bénardeau, A.; Pflieger, P.; Garriz, J.M.; Funder, J.W. Mechanisms underlying off-target effects of the cholesteryl ester transfer protein inhibitor torcetrapib involve L-type calcium channels. J. Hypertens. 2010, 28, 1676-1686. [CrossRef]

61. Rader, D.J.; Kastelein, J.J. Lomitapide and mipomersen: Two first-in-class drugs for reducing low-density lipoprotein cholesterol in patients with homozygous familial hypercholesterolemia. Circulation 2014, 129, 1022-1032. [CrossRef]

62. Adhyaru, B.B.; Jacobson, T.A. Safety and efficacy of statin therapy. Nat. Rev. Cardiol. 2018, 15, 757-769. [CrossRef]

63. Noto, D.; Cefalù, A.B.; Averna, M.R. Beyond statins: New lipid lowering strategies to reduce cardiovascular risk. Curr. Atheroscler. Rep. 2014, 16, 414. [CrossRef]

64. Insull, W., Jr. Clinical utility of bile acid sequestrants in the treatment of dyslipidemia: A scientific review. South. Med. J. 2006, 99, 257-274. [CrossRef]

65. Feng, X.; Zhang, L.; Xu, S.; Shen, A.-Z. ATP-citrate lyase (ACLY) in lipid metabolism and atherosclerosis: An updated review. Prog. Lipid Res. 2020, 77, 101006. [CrossRef]

66. Vaidya, S.; Bostedor, R.; Kurtz, M.M.; Bergstrom, J.D.; Bansal, V.S. Massive production of farnesol-derived dicarboxylic acids in mice treated with the squalene synthase inhibitor zaragozic acid A. Arch. Biochem. Biophys. 1998, 355, 84-92. [CrossRef]

67. Al-Dury, S.; Wahlström, A.; Wahlin, S.; Langedijk, J.; Elferink, R.O.; Ståhlman, M.; Marschall, H.-U. Pilot study with IBAT inhibitor A4250 for the treatment of cholestatic pruritus in primary biliary cholangitis. Sci. Rep. 2018, 8, 6658. [CrossRef]

68. Wu, M.; Xu, K.; Guo, Y.; Yu, J.; Wu, Y.; Lin, L. Lipoprotein (a) and atherosclerotic cardiovascular disease: Current understanding and future perspectives. Cardiovasc. Drugs Ther. 2019, 33, 739-748. [CrossRef]

69. Ward, N.C.; Watts, G.F.; Eckel, R.H. Statin toxicity: Mechanistic insights and clinical implications. Circ. Res. 2019, 124, 328-350. [CrossRef]

70. Neef, D.; Berthold, H.K.; Gouni-Berthold, I. Lomitapide for use in patients with homozygous familial hypercholesterolemia: A narrative review. Expert Rev. Clin. Pharmacol. 2016, 9, 655-663. [CrossRef]

71. Gouni-Berthold, I.; Berthold, H.K. Mipomersen and lomitapide: Two new drugs for the treatment of homozygous familial hypercholesterolemia. Atheroscler. Suppl. 2015, 18, 28-34. [CrossRef]

72. Aldridge, M.A.; Ito, M.K. Colesevelam hydrochloride: A novel bile acid-binding resin. Ann. Pharmacother. 2001, 35, 898-907. [CrossRef] 
73. Stein, E.A.; Bays, H.; O’Brien, D.; Pedicano, J.; Piper, E.; Spezzi, A. Lapaquistat acetate: Development of a squalene synthase inhibitor for the treatment of hypercholesterolemia. Circulation 2011, 123, 1974-1985. [CrossRef]

74. Kim, Y.; Keogh, J.B.; Clifton, P.M. Polyphenols and glycemic control. Nutrients 2016, 8, 17. [CrossRef]

75. Suh, J.-H.; Virsolvy, A.; Goux, A.; Cassan, C.; Richard, S.; Cristol, J.-P.; Teissedre, P.-L.; Rouanet, J.-M. Polyphenols prevent lipid abnormalities and arterial dysfunction in hamsters on a high-fat diet: A comparative study of red grape and white persimmon wines. Food Funct. 2011, 2, 555-561. [CrossRef]

76. Wu, A.H.; Spicer, D.; Stanczyk, F.Z.; Tseng, C.-C.; Yang, C.S.; Pike, M.C. Effect of 2-month controlled green tea intervention on lipoprotein cholesterol, glucose, and hormone levels in healthy postmenopausal women. Cancer Prev. Res. 2012, 5, 393-402. [CrossRef]

77. Johnson, S.A.; Navaei, N.; Pourafshar, S.; Jaime, S.J.; Akhavan, N.S.; Alvarez-Alvarado, S.; Proano, G.V.; Litwin, N.S.; Clark, E.A.; Foley, E.M.; et al. Effects of Montmorency Tart Cherry Juice Consumption on Cardiometabolic Biomarkers in Adults with Metabolic Syndrome: A Randomized Controlled Pilot Trial. J. Med. Food 2020, 23, 1238-1247. [CrossRef]

78. Wang, Z.; Tu, Z.; Xie, X.; Cui, H.; Kong, K.W.; Zhang, L. Perilla frutescens Leaf Extract and Fractions: Polyphenol Composition, Antioxidant, Enzymes (alpha-Glucosidase, Acetylcholinesterase, and Tyrosinase) Inhibitory, Anticancer, and Antidiabetic Activities. Foods 2021, 10, 315. [CrossRef]

79. Li, W.; Yang, C.; Mei, X.; Huang, R.; Zhang, S.; Tang, Y.; Dong, Q.; Zhou, C. Effect of the polyphenol-rich extract from Allium cepa on hyperlipidemic sprague-dawley rats. J. Food Biochem. 2021, 45, e13565. [CrossRef]

80. Yousefi, R.; Parandoosh, M.; Khorsandi, H.; Hosseinzadeh, N.; Tonekaboni, M.M.; Saidpour, A.; Babaei, H.; Ghorbani, A. Grape seed extract supplementation along with a restricted-calorie diet improves cardiovascular risk factors in obese or overweight adult individuals: A randomized, placebo-controlled trial. Phytother. Res. 2021, 35, 987-995. [CrossRef]

81. Sun, J.; Wang, Z.; Chen, L.; Sun, G. Hypolipidemic Effects and Preliminary Mechanism of Chrysanthemum Flavonoids, Its Main Components Luteolin and Luteoloside in Hyperlipidemia Rats. Antioxidants 2021, 10, 1309. [CrossRef]

82. Islam, M.S. Effects of the aqueous extract of white tea (Camellia sinensis) in a streptozotocin-induced diabetes model of rats. Phytomedicine 2011, 19, 25-31. [CrossRef]

83. Bornhoeft, J.; Castaneda, D.; Nemoseck, T.; Wang, P.; Henning, S.M.; Hong, M.Y. The protective effects of green tea polyphenols: Lipid profile, inflammation, and antioxidant capacity in rats fed an atherogenic diet and dextran sodium sulfate. J. Med. Food 2012, 15, 726-732. [CrossRef] [PubMed]

84. Li, Q.; Liu, Z.; Huang, J.; Luo, G.; Liang, Q.; Wang, D.; Ye, X.; Wu, C.; Wang, L.; Hu, J. Anti-obesity and hypolipidemic effects of Fuzhuan brick tea water extract in high-fat diet-induced obese rats. J. Sci. Food Agric. 2013, 93, 1310-1316. [CrossRef] [PubMed]

85. Bellassoued, K.; Ghrab, F.; Makni-Ayadi, F.; Pelt, J.V.; Elfeki, A.; Ammar, E. Protective effect of kombucha on rats fed a hypercholesterolemic diet is mediated by its antioxidant activity. Pharm. Biol. 2015, 53, 1699-1709. [CrossRef] [PubMed]

86. Zhu, Z.; Lin, Z.; Jiang, H.; Jiang, Y.; Zhao, M.; Liu, X. Hypolipidemic effect of Youcha in hyperlipidemia rats induced by high-fat diet. Food Funct. 2017, 8, 1680-1687. [CrossRef] [PubMed]

87. Guruvaiah, P.; Guo, H.; Li, D.; Xie, Z. Preventive effect of flavonol derivatives abundant sanglan tea on long-term high-fat-dietinduced obesity complications in c57bl/6 mice. Nutrients 2018, 10, 1276. [CrossRef]

88. Lin, R.; He, X.; Chen, H.; He, Q.; Yao, Z.; Li, Y.; Yang, H.; Simpson, S., Jr. Oil tea improves glucose and lipid levels and alters gut microbiota in type 2 diabetic mice. Nutr. Res. 2018, 57, 67-77. [CrossRef]

89. Liu, B.; Zhang, J.; Sun, P.; Yi, R.; Han, X.; Zhao, X. Raw Bowl Tea (Tuocha) Polyphenol Prevention of Nonalcoholic Fatty Liver Disease by Regulating Intestinal Function in Mice. Biomolecules 2019, 9, 435. [CrossRef]

90. Zhai, X.; Chi, J.; Tang, W.; Ji, Z.; Zhao, F.; Jiang, C.; Lv, H.; Guo, H. Yellow wine polyphenolic compounds inhibit matrix metalloproteinase-2,-9 expression and improve atherosclerotic plaque in LDL-receptor-knockout mice. J. Pharmacol. Sci. 2014, 125, 132-141. [CrossRef]

91. Peng, C.-H.; Liu, L.-K.; Chuang, C.-M.; Chyau, C.-C.; Huang, C.-N.; Wang, C.-J. Mulberry water extracts possess an anti-obesity effect and ability to inhibit hepatic lipogenesis and promote lipolysis. J. Agric. Food Chem. 2011, 59, 2663-2671. [CrossRef]

92. Suh, J.-H.; Romain, C.; González-Barrio, R.; Cristol, J.-P.; Teissèdre, P.-L.; Crozier, A.; Rouanet, J.-M. Raspberry juice consumption, oxidative stress and reduction of atherosclerosis risk factors in hypercholesterolemic golden Syrian hamsters. Food Funct. 2011, 2, 400-405. [CrossRef]

93. Liu, S.; You, L.; Zhao, Y.; Chang, X. Wild Lonicera caerulea berry polyphenol extract reduces cholesterol accumulation and enhances antioxidant capacity in vitro and in vivo. Food Res. Int. 2018, 107, 73-83. [CrossRef]

94. Liu, Y.; Zhang, X.; Zhan, L.; Xu, C.; Sun, L.; Jiang, H.; Sun, C.; Li, X. LC-Q-TOF-MS Characterization of Polyphenols from White Bayberry Fruit and Its Antidiabetic Effect in KK-A(y) Mice. ACS Omega 2020, 5, 17839-17849. [CrossRef]

95. Leontowicz, M.; Jesion, I.; Leontowicz, H.; Park, Y.-S.; Namiesnik, J.; Rombolà, A.D.; Weisz, M.; Gorinstein, S. Health-promoting effects of ethylene-treated kiwifruit 'Hayward' from conventional and organic crops in rats fed an atherogenic diet. J. Agric. Food Chem. 2013, 61, 3661-3668. [CrossRef]

96. Lim, C.Y.; Junit, S.M.; Abdulla, M.A.; Aziz, A.A. In vivo biochemical and gene expression analyses of the antioxidant activities and hypocholesterolaemic properties of Tamarindus indica fruit pulp extract. PLoS ONE 2013, 8, e70058. [CrossRef]

97. Xu, Z.-R.; Li, J.-Y.; Dong, X.-W.; Tan, Z.-J.; Wu, W.-Z.; Xie, Q.-M.; Yang, Y.-M. Apple polyphenols decrease atherosclerosis and hepatic steatosis in ApoE ${ }^{-/-}$mice through the ROS/MAPK/NF-kB pathway. Nutrients 2015, 7, 7085-7105. [CrossRef] 
98. Fathy, S.M.; Drees, E.A. Protective effects of Egyptian cloudy apple juice and apple peel extract on lipid peroxidation, antioxidant enzymes and inflammatory status in diabetic rat pancreas. BMC Complement. Med. Ther. 2015, 16, 8. [CrossRef]

99. Han, X.; Li, W.; Huang, D.; Yang, X. Polyphenols from hawthorn peels and fleshes differently mitigate dyslipidemia, inflammation and oxidative stress in association with modulation of liver injury in high fructose diet-fed mice. Chem. Biol. Interact. 2016, 257, 132-140. [CrossRef]

100. Alqarni, M.M.M.; Osman, M.A.; Al-Tamimi, D.S.; Gassem, M.A.; Al-Khalifa, A.S.; Al-Juhaimi, F.; Ahmed, I.A.M. Antioxidant and antihyperlipidemic effects of Ajwa date (Phoenix dactylifera L.) extracts in rats fed a cholesterol-rich diet. J. Food Biochem. 2019, 43, e12933. [CrossRef]

101. Peng, C.-H.; Chyau, C.-C.; Chan, K.-C.; Chan, T.-H.; Wang, C.-J.; Huang, C.-N. Hibiscus sabdariffa polyphenolic extract inhibits hyperglycemia, hyperlipidemia, and glycation-oxidative stress while improving insulin resistance. J. Agric. Food Chem. 2011, 59, 9901-9909. [CrossRef]

102. Kao, E.-S.; Yang, M.-Y.; Hung, C.-H.; Huang, C.-N.; Wang, C.-J. Polyphenolic extract from Hibiscus sabdariffa reduces body fat by inhibiting hepatic lipogenesis and preadipocyte adipogenesis. Food Funct. 2016, 7, 171-182. [CrossRef]

103. Daleprane, J.B.; Freitas, V.d.S.; Pacheco, A.; Rudnicki, M.; Faine, L.A.; Dörr, F.A.; Ikegaki, M.; Salazar, L.A.; Ong, T.P.; Abdalla, D.S.P. Anti-atherogenic and anti-angiogenic activities of polyphenols from propolis. J. Nutr. Biochem. 2012, 23, 557-566. [CrossRef] [PubMed]

104. Moniruzzaman, M.; Rokeya, B.; Ahmed, S.; Bhowmik, A.; Khalil, M.; Gan, S.H. In vitro antioxidant effects of Aloe barbadensis Miller extracts and the potential role of these extracts as antidiabetic and antilipidemic agents on streptozotocin-induced type 2 diabetic model rats. Molecules 2012, 17, 12851-12867. [CrossRef]

105. Wang, L.; Sun, J.; Yi, Q.; Wang, X.; Ju, X. Protective effect of polyphenols extract of adlay (Coix lachryma-jobi L. var. ma-yuen Stapf) on hypercholesterolemia-induced oxidative stress in rats. Molecules 2012, 17, 8886-8897. [CrossRef] [PubMed]

106. Musolino, V.; Gliozzi, M.; Scarano, F.; Bosco, F.; Scicchitano, M.; Nucera, S.; Carresi, C.; Ruga, S.; Zito, M.C.; Maiuolo, J.; et al. Bergamot Polyphenols Improve Dyslipidemia and Pathophysiological Features in a Mouse Model of Non-Alcoholic Fatty Liver Disease. Sci. Rep. 2020, 10, 2565. [CrossRef] [PubMed]

107. Sinaga, E.; Suprihatin; Yenisbar; Iswahyudi, M.; Setyowati, S.; Prasasty, V.D. Effect of supplementation of Rhodomyrtus tomentosa fruit juice in preventing hypercholesterolemia and atherosclerosis development in rats fed with fat cholesterol diet. Biomed. Pharmacother. 2021, 142, 111996. [CrossRef] [PubMed]

108. Wang, Z.; Li, X.-L.; Hong, K.-F.; Zhao, T.-T.; Dong, R.-X.; Wang, W.-M.; Li, Y.-T.; Zhang, G.-L.; Lin, J.; Gui, D.-K.; et al. Total flavonoids of Astragalus Ameliorated Bile Acid Metabolism Dysfunction in Diabetes Mellitus. Evid. Based Complement. Altern. Med. 2021, 2021, 6675567. [CrossRef]

109. Wang, M.; Wang, R.; Li, L.; Yan, Y.; Jia, S.; Jiang, H.; Du, Z. Quantitative proteomics of plasma and liver reveals the mechanism of turmeric in preventing hyperlipidemia in mice. Food Funct. 2021, 12, 10484-10499. [CrossRef] [PubMed]

110. Feriani, A.; Tir, M.; Arafah, M.; Gomez-Caravaca, A.M.; Contreras, M.d.M.; Nahdi, S.; Taamalli, A.; Allagui, M.S.; Alwasel, S.; Segura-Carretero, A.; et al. Schinus terebinthifolius fruits intake ameliorates metabolic disorders, inflammation, oxidative stress, and related vascular dysfunction, in atherogenic diet-induced obese rats. Insight of their chemical characterization using HPLC-ESI-QTOF-MS/MS. J. Ethnopharmacol. 2021, 269, 113701. [CrossRef]

111. Chen, I.-J.; Liu, C.-Y.; Chiu, J.-P.; Hsu, C.-H. Therapeutic effect of high-dose green tea extract on weight reduction: A randomized, double-blind, placebo-controlled clinical trial. Clin. Nutr. 2016, 35, 592-599. [CrossRef]

112. Lee, T.-M.; Charng, M.-J.; Tseng, C.-D.; Lai, L.-P. A Double-Blind, Randomized, Placebo-Controlled Study to Evaluate the Efficacy and Safety of STA-2 (Green Tea Polyphenols) in Patients with Chronic Stable Angina. Acta Cardiol. Sin. 2016, 32, 439-449. [CrossRef]

113. Quezada-Fernandez, P.; Trujillo-Quiros, J.; Pascoe-Gonzalez, S.; Trujillo-Rangel, W.A.; Cardona-Mueller, D.; Ramos-Becerra, C.G.; Barocio-Pantoja, M.; Rodriguez-de la Cerda, M.; Nerida Sanchez-Rodriguez, E.; Cardona-Munoz, E.G.; et al. Effect of green tea extract on arterial stiffness, lipid profile and sRAGE in patients with type 2 diabetes mellitus: A randomised, double-blind, placebo-controlled trial. Int. J. Food Sci. Nutr. 2019, 70, 977-985. [CrossRef]

114. Ishida, N.; Iizuka, M.; Kataoka, K.; Okazaki, M.; Shiraishi, K.; Yagi, Y.; Jobu, K.; Yokota, J.; Oishi, M.; Moriyama, H. Improvement of blood lipid profiles by goishi tea polyphenols in a randomised, double-blind, placebo-controlled clinical study. Int. J. Food Sci. Nutr. 2018, 69, 598-607. [CrossRef]

115. Kitada, M.; Ogura, Y.; Monno, I.; Koya, D. Supplementation with Red Wine Extract Increases Insulin Sensitivity and Peripheral Blood Mononuclear Sirt1 Expression in Nondiabetic Humans. Nutrients 2020, 12, 3108. [CrossRef]

116. Xie, L.; Vance, T.; Kim, B.; Lee, S.G.; Caceres, C.; Wang, Y.; Hubert, P.A.; Lee, J.-Y.; Chun, O.K.; Bolling, B.W. Aronia berry polyphenol consumption reduces plasma total and low-density lipoprotein cholesterol in former smokers without lowering biomarkers of inflammation and oxidative stress: A randomized controlled trial. Nutr. Res. 2017, 37, 67-77. [CrossRef]

117. Stote, K.S.; Wilson, M.M.; Hallenbeck, D.; Thomas, K.; Rourke, J.M.; Sweeney, M.I.; Gottschall-Pass, K.T.; Gosmanov, A.R. Effect of Blueberry Consumption on Cardiometabolic Health Parameters in Men with Type 2 Diabetes: An 8-Week, Double-Blind, Randomized, Placebo-Controlled Trial. Curr. Dev. Nutr. 2020, 4, nzaa030. [CrossRef]

118. Yubero, N.; Sanz-Buenhombre, M.; Guadarrama, A.; Villanueva, S.; Carrión, J.M.; Larrarte, E.; Moro, C. LDL cholesterol-lowering effects of grape extract used as a dietary supplement on healthy volunteers. Int. J. Food Sci. Nutr. 2013, 64, 400-406. [CrossRef] 
119. Rahbar, A.R.; Mahmoudabadi, M.M.S.; Islam, M.S. Comparative effects of red and white grapes on oxidative markers and lipidemic parameters in adult hypercholesterolemic humans. Food Funct. 2015, 6, 1992-1998. [CrossRef]

120. Sanchez Macarro, M.; Martinez Rodriguez, J.P.; Bernal Morell, E.; Perez-Pinero, S.; Victoria-Montesinos, D.; Maria GarciaMunoz, A.; Canovas Garcia, F.; Castillo Sanchez, J.; Javier Lopez-Roman, F. Effect of a Combination of Citrus Flavones and Flavanones and Olive Polyphenols for the Reduction of Cardiovascular Disease Risk: An Exploratory Randomized, Double-Blind, Placebo-Controlled Study in Healthy Subjects. Nutrients 2020, 12, 1475. [CrossRef]

121. Filip, R.; Possemiers, S.; Heyerick, A.; Pinheiro, I.; Raszewski, G.; Davicco, M.-J.; Coxam, V. Twelve-month consumption of a polyphenol extract from olive (Olea europaea) in a double blind, randomized trial increases serum total osteocalcin levels and improves serum lipid profiles in postmenopausal women with osteopenia. J. Nutr. Health Aging 2015, 19, 77-86. [CrossRef]

122. Georgakouli, K.; Mpesios, A.; Kouretas, D.; Petrotos, K.; Mitsagga, C.; Giavasis, I.; Jamurtas, A.Z. The effects of an olive fruit polyphenol-enriched yogurt on body composition, blood redox status, physiological and metabolic parameters and yogurt microflora. Nutrients 2016, 8, 344. [CrossRef]

123. Hosseini, B.; Saedisomeolia, A.; Wood, L.G.; Yaseri, M.; Tavasoli, S. Effects of pomegranate extract supplementation on inflammation in overweight and obese individuals: A randomized controlled clinical trial. Complement. Ther. Clin. Pract. 2016, 22, 44-50. [CrossRef] [PubMed]

124. Sohrab, G.; Roshan, H.; Ebrahimof, S.; Nikpayam, O.; Sotoudeh, G.; Siasi, F. Effects of pomegranate juice consumption on blood pressure and lipid profile in patients with type 2 diabetes: A single-blind randomized clinical trial. Clin. Nutr. ESPEN 2019, 29, 30-35. [CrossRef] [PubMed]

125. Chai, S.C.; Davis, K.; Wright, R.S.; Kuczmarski, M.F.; Zhang, Z. Impact of tart cherry juice on systolic blood pressure and low-density lipoprotein cholesterol in older adults: A randomized controlled trial. Food Funct. 2018, 9, 3185-3194. [CrossRef] [PubMed]

126. Shin, H.C.; Kim, S.H.; Park, Y.; Lee, B.H.; Hwang, H.J. Effects of 12-week oral supplementation of Ecklonia cava polyphenols on anthropometric and blood lipid parameters in overweight Korean individuals: A double-blind randomized clinical trial. Phytother. Res. 2012, 26, 363-368. [CrossRef]

127. Boots, A.W.; Haenen, G.R.M.M.; Bast, A. Health effects of quercetin: From antioxidant to nutraceutical. Eur. J. Pharmacol. 2008, 585, 325-337. [CrossRef]

128. Valentova, K.; Vrba, J.; Bancirova, M.; Ulrichova, J.; Kren, V. Isoquercitrin: Pharmacology, toxicology, and metabolism. Food Chem. Toxicol. 2014, 68, 267-282. [CrossRef]

129. Salvamani, S.; Gunasekaran, B.; Shaharuddin, N.A.; Ahmad, S.A.; Shukor, M.Y. Antiartherosclerotic Effects of Plant Flavonoids. Biomed. Res. Int. 2014, 2014, 48058. [CrossRef]

130. Nickel, T.; Hanssen, H.; Sisic, Z.; Pfeiler, S.; Summo, C.; Schmauss, D.; Hoster, E.; Weis, M. Immunoregulatory effects of the flavonol quercetin in vitro and in vivo. Eur. J. Nutr. 2011, 50, 163-172. [CrossRef]

131. Jeong, S.-M.; Kang, M.-J.; Choi, H.-N.; Kim, J.-H.; Kim, J.-I. Quercetin ameliorates hyperglycemia and dyslipidemia and improves antioxidant status in type 2 diabetic db/db mice. Nutr. Res. Pract. 2012, 6, 201-207. [CrossRef]

132. Ying, H.-Z.; Liu, Y.-H.; Yu, B.; Wang, Z.-Y.; Zang, J.-N.; Yu, C.-H. Dietary quercetin ameliorates nonalcoholic steatohepatitis induced by a high-fat diet in gerbils. Food Chem. Toxicol. 2013, 52, 53-60. [CrossRef]

133. Li, S.-S.; Cao, H.; Shen, D.-Z.; Chen, C.; Xing, S.-L.; Dou, F.-F.; Jia, Q.-L. Effect of Quercetin on Atherosclerosis Based on Expressions of ABCA1, LXR-alpha and PCSK9 in ApoE(-/-) Mice. Chin. J. Integr. Med. 2020, 26, 114-121. [CrossRef]

134. Mbikay, M.; Mayne, J.; Sirois, F.; Fedoryak, O.; Raymond, A.; Noad, J.; Chretien, M. Mice Fed a High-Cholesterol Diet Supplemented with Quercetin-3-Glucoside Show Attenuated Hyperlipidemia and Hyperinsulinemia Associated with Differential Regulation of PCSK9 and LDLR in their Liver and Pancreas. Mol. Nutr. Food Res. 2018, 62, e1700729. [CrossRef]

135. Lu, T.-M.; Chiu, H.-F.; Shen, Y.-C.; Chung, C.-C.; Venkatakrishnan, K.; Wang, C.-K. Hypocholesterolemic Efficacy of Quercetin Rich Onion Juice in Healthy Mild Hypercholesterolemic Adults: A Pilot Study. Plant Foods Hum. Nutr. 2015, 70, 395-400. [CrossRef]

136. Nekohashi, M.; Ogawa, M.; Ogihara, T.; Nakazawa, K.; Kato, H.; Misaka, T.; Abe, K.; Kobayashi, S. Luteolin and Quercetin Affect the Cholesterol Absorption Mediated by Epithelial Cholesterol Transporter Niemann-Pick C1-Like 1 in Caco-2 Cells and Rats. PLoS ONE 2014, 9, e97901. [CrossRef]

137. Moon, J.; Lee, S.-M.; Do, H.J.; Cho, Y.; Chung, J.H.; Shin, M.-J. Quercetin Up-regulates LDL Receptor Expression in HepG2 Cells. Phytother. Res. 2012, 26, 1688-1694. [CrossRef]

138. Mbikay, M.; Sirois, F.; Simoes, S.; Mayne, J.; Chretien, M. Quercetin-3-glucoside increases low-density lipoprotein receptor (LDLR) expression, attenuates proprotein convertase subtilisin/kexin 9 (PCSK9) secretion, and stimulates LDL uptake by Huh7 human hepatocytes in culture. FEBS Open Bio 2014, 4, 755-762. [CrossRef]

139. Zhang, M.; Xie, Z.; Gao, W.; Pu, L.; Wei, J.; Guo, C. Quercetin regulates hepatic cholesterol metabolism by promoting cholesterolto-bile acid conversion and cholesterol efflux in rats. Nutr. Res. 2016, 36, 271-279. [CrossRef]

140. Eng, Q.Y.; Thanikachalam, P.V.; Ramamurthy, S. Molecular understanding of Epigallocatechin gallate (EGCG) in cardiovascular and metabolic diseases. J. Ethnopharmacol. 2018, 210, 296-310. [CrossRef]

141. Moon, H.-S.; Chung, C.-S.; Lee, H.-G.; Kim, T.-G.; Choi, Y.-J.; Cho, C.-S. Inhibitory effect of (-)-epigallocatechin-3-gallate on lipid accumulation of 3T3-L1 cells. Obesity 2007, 15, 2571-2582. [CrossRef] 
142. Guo, Q.N.; Zhao, B.L.; Li, M.F.; Shen, S.R.; Xin, W.J. Studies on protective mechanisms of four components of green tea polyphenols against lipid peroxidation in synaptosomes. Biochim. Biophys. Acta Mol. Cell Biol. Lipids 1996, 1304, 210-222. [CrossRef]

143. Khalatbary, A.R.; Ahmadvand, H. Anti-inflammatory effect of the epigallocatechin gallate following spinal cord trauma in rat. Iran. Biomed. J. 2011, 15, 31-37.

144. Ren, Z.; Yang, Z.; Lu, Y.; Zhang, R.; Yang, H. Anti-glycolipid disorder effect of epigallocatechin-3-gallate on high-fat diet and STZ-induced T2DM in mice. Mol. Med. Rep. 2020, 21, 2475-2483. [CrossRef]

145. Hirsova, P.; Kolouchova, G.; Dolezelova, E.; Cermanova, J.; Hyspler, R.; Kadova, Z.; Micuda, S. Epigallocatechin gallate enhances biliary cholesterol secretion in healthy rats and lowers plasma and liver cholesterol in ethinylestradiol-treated rats. Eur. J. Pharmacol. 2012, 691, 38-45. [CrossRef]

146. Li, Y.; Wu, S. Epigallocatechin gallate suppresses hepatic cholesterol synthesis by targeting SREBP-2 through SIRT1/FOXO1 signaling pathway. Mol. Cell. Biochem. 2018, 448, 175-185. [CrossRef] [PubMed]

147. Cui, C.-J.; Jin, J.-L.; Guo, L.-N.; Sun, J.; Wu, N.-Q.; Guo, Y.-L.; Liu, G.; Dong, Q.; Li, J.-J. Beneficial impact of epigallocatechingallate on LDL-C through PCSK9/LDLR pathway by blocking HNF1 $\alpha$ and activating FoxO3a. J. Transl. Med. 2020, 18, 195. [CrossRef] [PubMed]

148. Mielgo-Ayuso, J.; Barrenechea, L.; Alcorta, P.; Larrarte, E.; Margareto, J.; Labayen, I. Effects of dietary supplementation with epigallocatechin-3-gallate on weight loss, energy homeostasis, cardiometabolic risk factors and liver function in obese women: Randomised, double-blind, placebo-controlled clinical trial. Br. J. Nutr. 2014, 111, 1263-1271. [CrossRef] [PubMed]

149. Brown, A.L.; Lane, J.; Coverly, J.; Stocks, J.; Jackson, S.; Stephen, A.; Bluck, L.; Coward, A.; Hendrickx, H. Effects of dietary supplementation with the green tea polyphenol epigallocatechin-3-gallate on insulin resistance and associated metabolic risk factors: Randomized controlled trial. Br. J. Nutr. 2009, 101, 886-894. [CrossRef]

150. Momose, Y.; Maeda-Yamamoto, M.; Nabetani, H. Systematic review of green tea epigallocatechin gallate in reducing low-density lipoprotein cholesterol levels of humans. Int. J. Food Sci. Nutr. 2016, 67, 606-613. [CrossRef]

151. Huang, J.; Feng, S.; Liu, A.; Dai, Z.; Wang, H.; Reuhl, K.; Lu, W.; Yang, C.S. Green Tea Polyphenol EGCG Alleviates Metabolic Abnormality and Fatty Liver by Decreasing Bile Acid and Lipid Absorption in Mice. Mol. Nutr. Food Res. 2018, 62, 1700696. [CrossRef]

152. Raederstorff, D.G.; Schlachter, M.F.; Elste, V.; Weber, P. Effect of EGCG on lipid absorption and plasma lipid levels in rats. J. Nutr. Biochem. 2003, 14, 326-332. [CrossRef]

153. Kitamura, K.; Okada, Y.; Okada, K.; Kawaguchi, Y.; Nagaoka, S. Epigallocatechin gallate induces an up-regulation of LDL receptor accompanied by a reduction of PCSK9 via the annexin A2-independent pathway in HepG2 cells. Mol. Nutr. Food Res. 2017, 61, 1600836. [CrossRef]

154. Poirier, S.; Mayer, G.; Benjannet, S.; Bergeron, E.; Marcinkiewicz, J.; Nassoury, N.; Mayer, H.; Nimpf, J.; Prat, A.; Seidah, N.G. The proprotein convertase PCSK9 induces the degradation of low density lipoprotein receptor (LDLR) and its closest family members VLDLR and ApoER2. J. Biol. Chem. 2008, 283, 2363-2372. [CrossRef]

155. Kuhn, D.J.; Burns, A.C.; Kazi, A.; Dou, Q.P. Direct inhibition of the ubiquitin-proteasome pathway by ester bond-containing green tea polyphenols is associated with increased expression of sterol regulatory element-binding protein 2 and LDL receptor. Biochim. Biophys. Acta Mol. Cell Biol. Lipids 2004, 1682, 1-10. [CrossRef]

156. He, J.; Giusti, M.M. Anthocyanins: Natural Colorants with Health-Promoting Properties. Annu. Rev. Food Sci. Technol. 2010, 1, 163-187. [CrossRef]

157. Wang, Y.; Zhao, L.; Wang, D.; Huo, Y.; Ji, B. Anthocyanin-rich extracts from blackberry, wild blueberry, strawberry, and chokeberry: Antioxidant activity and inhibitory effect on oleic acid-induced hepatic steatosis in vitro. J. Sci. Food Agric. 2016, 96, $2494-2503$. [CrossRef]

158. Hassellund, S.S.; Flaa, A.; Kjeldsen, S.E.; Seljeflot, I.; Karlsen, A.; Erlund, I.; Rostrup, M. Effects of anthocyanins on cardiovascular risk factors and inflammation in pre-hypertensive men: A double-blind randomized placebo-controlled crossover study. J. Hum. Hypertens. 2013, 27, 100-106. [CrossRef]

159. Aboonabi, A.; Meyer, R.R.; Gaiz, A.; Singh, I. Anthocyanins in berries exhibited anti-atherogenicity and antiplatelet activities in a metabolic syndrome population. Nutr. Res. 2020, 76, 82-93. [CrossRef]

160. Xia, M.; Hou, M.; Zhu, H.; Ma, J.; Tang, Z.; Wang, Q.; Li, Y.; Chi, D.; Yu, X.; Zhao, T.; et al. Anthocyanins induce cholesterol efflux from mouse peritoneal macrophages: The role of the peroxisome proliferator-activated receptor $\{$ gamma\}-liver $X$ receptor \{alpha\}-ABCA1 pathway. J. Biol. Chem. 2005, 280, 36792-36801. [CrossRef]

161. Kianbakht, S.; Abasi, B.; Dabaghian, F.H. Improved Lipid Profile in Hyperlipidemic Patients Taking Vaccinium arctostaphylos Fruit Hydroalcoholic Extract: A Randomized Double-Blind Placebo-Controlled Clinical Trial. Phytother. Res. 2014, 28 , $432-436$. [CrossRef]

162. Qin, Y.; Xia, M.; Ma, J.; Hao, Y.; Liu, J.; Mou, H.; Cao, L.; Ling, W. Anthocyanin supplementation improves serum LDL- and HDL-cholesterol concentrations associated with the inhibition of cholesteryl ester transfer protein in dyslipidemic subjects. Am. J. Clin. Nutr. 2009, 90, 485-492. [CrossRef]

163. Soltani, R.; Hakimi, M.; Asgary, S.; Ghanadian, S.M.; Keshvari, M.; Sarrafzadegan, N. Evaluation of the Effects of Vaccinium arctostaphylos L. Fruit Extract on Serum Lipids and hs-CRP Levels and Oxidative Stress in Adult Patients with Hyperlipidemia: A Randomized, Double-Blind, Placebo-Controlled Clinical Trial. Evid. Based Complement. Altern. Med. 2014, $2014,217451$. [CrossRef] 
164. Zhu, Y.; Ling, W.; Guo, H.; Song, F.; Ye, Q.; Zou, T.; Li, D.; Zhang, Y.; Li, G.; Xiao, Y.; et al. Anti-inflammatory effect of purified dietary anthocyanin in adults with hypercholesterolemia: A randomized controlled trial. Nutr. Metab. Cardiovasc. Dis. 2013, 23, 843-849. [CrossRef]

165. Bakuradze, T.; Tausend, A.; Galan, J.; Groh, I.A.M.; Berry, D.; Tur, J.A.; Marko, D.; Richling, E. Antioxidative activity and health benefits of anthocyanin-rich fruit juice in healthy volunteers. Free Radic. Res. 2019, 53, 1045-1055. [CrossRef]

166. Zhang, P.-W.; Chen, F.-X.; Li, D.; Ling, W.-H.; Guo, H.-H. A CONSORT-Compliant, Randomized, Double-Blind, Placebo-Controlled Pilot Trial of Purified Anthocyanin in Patients with Nonalcoholic Fatty Liver Disease. Medicine 2015, 94, e758. [CrossRef]

167. Yang, L.; Ling, W.; Du, Z.; Chen, Y.; Li, D.; Deng, S.; Liu, Z.; Yang, L. Effects of Anthocyanins on Cardiometabolic Health: A Systematic Review and Meta-Analysis of Randomized Controlled Trials. Adv. Nutr. 2017, 8, 684-693. [CrossRef]

168. Liu, C.; Sun, J.; Lu, Y.; Bo, Y. Effects of Anthocyanin on Serum Lipids in Dyslipidemia Patients: A Systematic Review and Meta-Analysis. PLoS ONE 2016, 11, e0162089. [CrossRef]

169. Liang, Y.; Chen, J.; Zuo, Y.; Ma, K.Y.; Jiang, Y.; Huang, Y.; Chen, Z.-Y. Blueberry anthocyanins at doses of 0.5 and $1 \%$ lowered plasma cholesterol by increasing fecal excretion of acidic and neutral sterols in hamsters fed a cholesterol-enriched diet. Eur. J. Nutr. 2013, 52, 869-875. [CrossRef]

170. Wang, L.; Zhu, H.; Zhao, Y.; Jiao, R.; Lei, L.; Chen, J.; Wang, X.; Zhang, Z.; Huang, Y.; Wang, T.; et al. Cranberry anthocyanin as an herbal medicine lowers plasma cholesterol by increasing excretion of fecal sterols. Phytomedicine 2018, 38, 98-106. [CrossRef] [PubMed]

171. Thilavech, T.; Adisakwattana, S. Cyanidin-3-rutinoside acts as a natural inhibitor of intestinal lipid digestion and absorption. BMC Complement. Med. Ther. 2019, 19, 242. [CrossRef] [PubMed]

172. Yao, S.-L.; Xu, Y.; Zhang, Y.-Y.; Lu, Y.-H. Black rice and anthocyanins induce inhibition of cholesterol absorption in vitro. Food Funct. 2013, 4, 1602-1608. [CrossRef] [PubMed]

173. Wang, D.; Xia, M.; Gao, S.; Li, D.; Zhang, Y.; Jin, T.; Ling, W. Cyanidin-3-O- $\beta$-glucoside upregulates hepatic cholesterol $7 \alpha$-hydroxylase expression and reduces hypercholesterolemia in mice. Mol. Nutr. Food Res. 2012, 56, 610-621. [CrossRef]

174. Aron, P.M.; Kennedy, J.A. Flavan-3-ols: Nature, occurrence and biological activity. Mol. Nutr. Food Res. 2008, 52, 79-104. [CrossRef]

175. De la Iglesia, R.; Milagro, F.I.; Campión, J.; Boqué, N.; Martínez, J.A. Healthy properties of proanthocyanidins. BioFactors 2010, 36, 159-168. [CrossRef]

176. Cao, J.; Yu, X.; Deng, Z.; Pan, Y.; Zhang, B.; Tsao, R.; Li, H. Chemical Compositions, Antiobesity, and Antioxidant Effects of Proanthocyanidins from Lotus Seed Epicarp and Lotus Seed Pot. J. Agric. Food Chem. 2018, 66, 13492-13502. [CrossRef]

177. Zhou, Q.; Han, X.; Li, R.; Zhao, W.; Bai, B.; Yan, C.; Dong, X. Anti-atherosclerosis of oligomeric proanthocyanidins from Rhodiola rosea on rat model via hypolipemic, antioxidant, anti-inflammatory activities together with regulation of endothelial function. Phytomedicine Int. J. Phytother. Phytopharm. 2018, 51, 171-180. [CrossRef]

178. Wang, Z.; Su, B.; Fan, S.; Fei, H.; Zhao, W. Protective effect of oligomeric proanthocyanidins against alcohol-induced liver steatosis and injury in mice. Biochem. Biophys. Res. Commun. 2015, 458, 757-762. [CrossRef]

179. Jiao, R.; Zhang, Z.; Yu, H.; Huang, Y.; Chen, Z.-Y. Hypocholesterolemic activity of grape seed proanthocyanidin is mediated by enhancement of bile acid excretion and up-regulation of CYP7A1. J. Nutr. Biochem. 2010, 21, 1134-1139. [CrossRef]

180. Yasuda, A.; Natsume, M.; Sasaki, K.; Baba, S.; Nakamura, Y.; Kanegae, M.; Nagaoka, S. Cacao procyanidins reduce plasma cholesterol and increase fecal steroid excretion in rats fed a high-cholesterol diet. BioFactors 2008, 33, 211-223. [CrossRef]

181. Heidker, R.M.; Caiozzi, G.C.; Ricketts, M.-L. Dietary procyanidins selectively modulate intestinal farnesoid X receptor-regulated gene expression to alter enterohepatic bile acid recirculation: Elucidation of a novel mechanism to reduce triglyceridemia. Mol. Nutr. Food Res. 2016, 60, 727-736. [CrossRef]

182. Quesada, H.; del Bas, J.M.; Pajuelo, D.; Diaz, S.; Fernandez-Larrea, J.; Pinent, M.; Arola, L.; Salvado, M.J.; Blade, C. Grape seed proanthocyanidins correct dyslipidemia associated with a high-fat diet in rats and repress genes controlling lipogenesis and VLDL assembling in liver. Int. J. Obes. 2009, 33, 1007-1012. [CrossRef]

183. Prasad, S.; Gupta, S.C.; Tyagi, A.K.; Aggarwal, B.B. Curcumin, a component of golden spice: From bedside to bench and back Biotechnol. Adv. 2014, 32, 1053-1064. [CrossRef] [PubMed]

184. Kunnumakkara, A.B.; Bordoloi, D.; Padmavathi, G.; Monisha, J.; Roy, N.K.; Prasad, S.; Aggarwal, B.B. Curcumin, the golden nutraceutical: Multitargeting for multiple chronic diseases. Br. J. Pharmacol. 2017, 174, 1325-1348. [CrossRef] [PubMed]

185. Panahi, Y.; Kianpour, P.; Mohtashami, R.; Jafari, R.; Simental-Mendía, L.E.; Sahebkar, A. Curcumin Lowers Serum Lipids and Uric Acid in Subjects with Nonalcoholic Fatty Liver Disease: A Randomized Controlled Trial. J. Cardiovasc. Pharmacol. 2016, 68, 223-229. [CrossRef] [PubMed]

186. Feng, D.; Zou, J.; Zhang, S.; Li, X.; Lu, M. Hypocholesterolemic Activity of Curcumin Is Mediated by Down-regulating the Expression of Niemann-Pick C1-like 1 in Hamsters. J. Agric. Food Chem. 2017, 65, 276-280. [CrossRef]

187. Zou, J.; Zhang, S.; Li, P.; Zheng, X.; Feng, D. Supplementation with curcumin inhibits intestinal cholesterol absorption and prevents atherosclerosis in high-fat diet-fed apolipoprotein E knockout mice. Nutr. Res. 2018, 56, 32-40. [CrossRef]

188. Kim, M.; Kim, Y. Hypocholesterolemic effects of curcumin via up-regulation of cholesterol 7a-hydroxylase in rats fed a high fat diet. Nutr. Res. Pract. 2010, 4, 191-195. [CrossRef] 
189. Momtazi-Borojeni, A.A.; Zabihi, N.A.; Bagheri, R.K.; Majeed, M.; Jamialahmadi, T.; Sahebkar, A. Intravenous Curcumin Mitigates Atherosclerosis Progression in Cholesterol-Fed Rabbits. In Pharmacological Properties of Plant-Derived Natural Products and Implications for Human Health; Barreto, G.E., Sahebkar, A., Eds.; Springer: Berlin/Heidelberg, Germany, 2021; Volume 1308, pp. $45-54$.

190. Labban, R.S.M.; Alfawaz, H.A.; Almnaizel, A.T.; Al-Muammar, M.N.; Bhat, R.S.; El-Ansary, A. Garcinia mangostana extract and curcumin ameliorate oxidative stress, dyslipidemia, and hyperglycemia in high fat diet-induced obese Wistar albino rats. Sci. Rep. 2021, 11, 7278. [CrossRef]

191. Jamilian, M.; Foroozanfard, F.; Kavossian, E.; Aghadavod, E.; Shafabakhsh, R.; Hoseini, A.; Asemi, Z. Effects of curcumin on body weight, glycemic control and serum lipids in women with polycystic ovary syndrome: A randomized, double-blind, placebo-controlled trial. Clin. Nutr. ESPEN 2020, 36, 128-133. [CrossRef]

192. Jalali, M.; Mahmoodi, M.; Mosallanezhad, Z.; Jalali, R.; Imanieh, M.H.; Moosavian, S.P. The effects of curcumin supplementation on liver function, metabolic profile and body composition in patients with non-alcoholic fatty liver disease: A systematic review and meta-analysis of randomized controlled trials. Complement. Ther. Med. 2020, 48, 102283. [CrossRef]

193. Funamoto, M.; Sunagawa, Y.; Katanasaka, Y.; Miyazaki, Y.; Imaizumi, A.; Kakeya, H.; Yamakage, H.; Satoh-Asahara, N.; Komiyama, M.; Wada, H.; et al. Highly absorptive curcumin reduces serum atherosclerotic low-density lipoprotein levels in patients with mild COPD. Int. J. Chron. Obstruct. Pulmon. Dis. 2016, 11, 2029-2034. [CrossRef]

194. Adibian, M.; Hodaei, H.; Nikpayam, O.; Sohrab, G.; Hekmatdoost, A.; Hedayati, M. The effects of curcumin supplementation on high-sensitivity C-reactive protein, serum adiponectin, and lipid profile in patients with type 2 diabetes: A randomized, double-blind, placebo-controlled trial. Phytother. Res. 2019, 33, 1374-1383. [CrossRef]

195. Feng, D.; Ohlsson, L.; Duan, R.-D. Curcumin inhibits cholesterol uptake in Caco-2 cells by down-regulation of NPC1L1 expression. Lipids Health Dis. 2010, 9, 40. [CrossRef]

196. Fan, C.; Wo, X.; Dou, X.; Xu, L.; Qian, Y.; Luo, Y.; Yan, J. Regulation of LDL receptor expression by the effect of curcumin on sterol regulatory element pathway. Pharmacol. Rep. 2006, 58, 577-581.

197. Dou, X.; Fan, C.; Wo, L.; Yan, J.; Qian, Y.; Wo, X. Curcumin Up-Regulates LDL Receptor Expression via the Sterol Regulatory Element Pathway in HepG2 Cells. Planta Med. 2008, 74, 1374-1379. [CrossRef]

198. Tai, M.-H.; Chen, P.-K.; Chen, P.-Y.; Wu, M.-J.; Ho, C.-T.; Yen, J.-H. Curcumin enhances cell-surface LDLR level and promotes LDL uptake through downregulation of PCSK9 gene expression in HepG2 cells. Mol. Nutr. Food Res. 2014, 58, 2133-2145. [CrossRef]

199. Cai, Y.; Lu, D.; Zou, Y.; Zhou, C.; Liu, H.; Tu, C.; Li, F.; Liu, L.; Zhang, S. Curcumin Protects Against Intestinal Origin Endotoxemia in Rat Liver Cirrhosis by Targeting PCSK9. J. Food Sci. 2017, 82, 772-780. [CrossRef]

200. Tian, N.; Li, X.; Luo, Y.; Han, Z.; Li, Z.; Fan, C. Curcumin regulates the metabolism of low density lipoproteins by improving the C-to-U RNA editing efficiency of apolipoprotein B in primary rat hepatocytes. Mol. Med. Rep. 2014, 9, 132-136. [CrossRef]

201. Hussain, H.; Green, I.R. A patent review of the therapeutic potential of isoflavones (2012-2016). Expert Opin. Ther. Pat. 2017, 27, 1135-1146. [CrossRef]

202. Mazumder, M.A.R.; Hongsprabhas, P. Genistein as antioxidant and antibrowning agents in in vivo and in vitro: A review. Biomed. Pharmacother. 2016, 82, 379-392. [CrossRef]

203. Usui, T. Pharmaceutical prospects of phytoestrogens. Endocr. J. 2006, 53, 7-20. [CrossRef]

204. Behloul, N.; Wu, G. Genistein: A promising therapeutic agent for obesity and diabetes treatment. Eur. J. Pharmacol. 2013, 698, 31-38. [CrossRef]

205. Yousefinejad, A.; Siassi, F.; Javanbakht, M.H.; Mohammadi, H.; Ghaedi, E.; Zarei, M.; Djalali, E.; Djalali, M. Effect of Genistein and L-carnitine and Their Combination on Lipid Profile and Inflammatory Cytokines in Experimental Nephrotic Syndrome. Rep. Biochem. Mol. Biol. 2018, 7, 1-8.

206. Incir, S.; Bolayirli, I.M.; Inan, O.; Aydin, M.S.; Bilgin, I.A.; Sayan, I.; Esrefoglu, M.; Seven, A. The effects of genistein supplementation on fructose induced insulin resistance, oxidative stress and inflammation. Life Sci. 2016, 158, 57-62. [CrossRef]

207. Tang, C.; Zhang, K.; Zhao, Q.; Zhang, J. Effects of Dietary Genistein on Plasma and Liver Lipids, Hepatic Gene Expression, and Plasma Metabolic Profiles of Hamsters with Diet-Induced Hyperlipidemia. J. Agric. Food Chem. 2015, 63, 7929-7936. [CrossRef]

208. Yin, Y.; Liu, H.; Zheng, Z.; Lu, R.; Jiang, Z. Genistein can ameliorate hepatic inflammatory reaction in nonalcoholic steatohepatitis rats. Biomed. Pharmacother. 2019, 111, 1290-1296. [CrossRef]

209. Amerizadeh, A.; Asgary, S.; Vaseghi, G.; Farajzadegan, Z. Effect of Genistein Intake on Some Cardiovascular Risk Factors: An Updated Systematic Review and Meta-analysis. Curr. Probl. Cardiol. 2021, 1, 100902. [CrossRef]

210. Squadrito, F.; Marini, H.; Bitto, A.; Altavilla, D.; Polito, F.; Adamo, E.B.; D'Anna, R.; Arcoraci, V.; Burnett, B.P.; Minutoli, L.; et al. Genistein in the Metabolic Syndrome: Results of a Randomized Clinical Trial. J. Clin. Endocrinol. Metab. 2013, 98, 3366-3374. [CrossRef]

211. Li, J.; Liu, Y.; Wang, T.; Zhao, L.; Feng, W. Does genistein lower plasma lipids and homocysteine levels in postmenopausal women? A meta-analysis. Climacteric 2016, 19, 440-447. [CrossRef]

212. Lu, R.; Zheng, Z.; Yin, Y.; Jiang, Z. Effect of Genistein on Cholesterol Metabolism-Related Genes in HepG2 Cell. J. Food Sci. 2019, 84, 2330-2336. [CrossRef]

213. Kartawijaya, M.; Han, H.W.; Kim, Y.; Lee, S.-M. Genistein upregulates LDLR levels via JNK-mediated activation of SREBP-2. Food Nutr. Res. 2016, 60, 31120. [CrossRef] 
214. Borradaile, N.M.; de Dreu, L.E.; Wilcox, L.J.; Edwards, J.Y.; Huff, M.W. Soya phytoestrogens, genistein and daidzein, decrease apolipoprotein B secretion from HepG2 cells through multiple mechanisms. Biochem. J. 2002, 366, 531-539. [CrossRef] [PubMed]

215. Giovinazzo, G.; Ingrosso, I.; Paradiso, A.; De Gara, L.; Santino, A. Resveratrol Biosynthesis: Plant Metabolic Engineering for Nutritional Improvement of Food. Plant Foods Hum. Nutr. 2012, 67, 191-199. [CrossRef] [PubMed]

216. Ravagnan, G.; De Filippis, A.; Carteni, M.; De Maria, S.; Cozza, V.; Petrazzuolo, M.; Tufano, M.A.; Donnarumma, G. Polydatin, A Natural Precursor of Resveratrol, Induces beta-Defensin Production and Reduces Inflammatory Response. Inflammation 2013, 36, 26-34. [CrossRef] [PubMed]

217. Jeon, S.-M.; Lee, S.-A.; Choi, M.-S. Antiobesity and Vasoprotective Effects of Resveratrol in ApoE-Deficient Mice. J. Med. Food 2014, 17, 310-316. [CrossRef]

218. Du, J.; Sun, L.-N.; Xing, W.-W.; Huang, B.-K.; Jia, M.; Wu, J.-Z.; Zhang, H.; Qin, L.-P. Lipid-lowering effects of polydatin from Polygonum cuspidatum in hyperlipidemic hamsters. Phytomedicine 2009, 16, 652-658. [CrossRef]

219. Xing, W.-W.; Wu, J.-Z.; Jia, M.; Du, J.; Zhang, H.; Qin, L.-P. Effects of polydatin from Polygonum cuspidatum on lipid profile in hyperlipidemic rabbits. Biomed. Pharmacother. 2009, 63, 457-462. [CrossRef]

220. Xin, P.; Han, H.; Gao, D.; Cui, W.; Yang, X.; Ying, C.; Sun, X.; Hao, L. Alleviative effects of resveratrol on nonalcoholic fatty liver disease are associated with up regulation of hepatic low density lipoprotein receptor and scavenger receptor class $B$ type I gene expressions in rats. Food Chem. Toxicol. 2013, 52, 12-18. [CrossRef]

221. Yashiro, T.; Nanmoku, M.; Shimizu, M.; Inoue, J.; Sato, R. Resveratrol increases the expression and activity of the low density lipoprotein receptor in hepatocytes by the proteolytic activation of the sterol regulatory element-binding proteins. Atherosclerosis 2012, 220, 369-374. [CrossRef]

222. Jing, Y.; Hu, T.; Lin, C.; Xiong, Q.; Liu, F.; Yuan, J.; Zhao, X.; Wang, R. Resveratrol downregulates PCSK9 expression and attenuates steatosis through estrogen receptor alpha-mediated pathway in L02 cells. Eur. J. Pharmacol. 2019, 855, 216-226. [CrossRef]

223. Wang, Y.; Ye, J.; Li, J.; Chen, C.; Huang, J.; Liu, P.; Huang, H. Polydatin ameliorates lipid and glucose metabolism in type 2 diabetes mellitus by downregulating proprotein convertase subtilisin/kexin type 9 (PCSK9). Cardiovasc. Diabetol. 2016, 15, 19. [CrossRef]

224. Chothe, P.P.; Swaan, P.W. Resveratrol promotes degradation of the human bile acid transporter ASBT (SLC10A2). Biochem. J. 2014, 459, 301-312. [CrossRef]

225. Miura, D.; Miura, Y.; Yagasaki, K. Hypolipidemic action of dietary resveratrol, a phytoalexin in grapes and red wine, in hepatoma-bearing rats. Life Sci. 2003, 73, 1393-1400. [CrossRef]

226. Kumar, S.; Prahalathan, P.; Saravanakumar, M.; Raja, B. Vanillic acid prevents the deregulation of lipid metabolism, endothelin 1 and up regulation of endothelial nitric oxide synthase in nitric oxide deficient hypertensive rats. Eur. J. Pharmacol. 2014, 743, 117-125. [CrossRef]

227. Ma, J.-Q.; Ding, J.; Zhao, H.; Liu, C.-M. Puerarin attenuates carbon tetrachloride-induced liver oxidative stress and hyperlipidaemia in mouse by JNK/c-Jun/CYP7A1 pathway. Basic Clin. Pharmacol. Toxicol. 2014, 115, 389-395. [CrossRef]

228. Sui, G.-G.; Xiao, H.-B.; Lu, X.-Y.; Sun, Z.-L. Naringin Activates AMPK Resulting in Altered Expression of SREBPs, PCSK9, and LDLR To Reduce Body Weight in Obese C57BL/6J Mice. J. Agric. Food Chem. 2018, 66, 8983-8990. [CrossRef]

229. Kubota, S.; Tanaka, Y.; Nagaoka, S. Ellagic acid affects mRNA expression levels of genes that regulate cholesterol metabolism in HepG2 cells. Biosci. Biotechnol. Biochem. 2019, 83, 952-959. [CrossRef]

230. Ochiai, A.; Miyata, S.; Iwase, M.; Shimizu, M.; Inoue, J.; Sato, R. Kaempferol stimulates gene expression of low-density lipoprotein receptor through activation of Sp1 in cultured hepatocytes. Sci. Rep. 2016, 6, 24940. [CrossRef]

231. Tamura, A.; Fukushima, M.; Shimada, K.-i.; Han, K.-H.; Sekikawa, M.; Watanabe, S.; Nakano, M.; Matsumoto, M.; Chiji, H. Cholesterol metabolism in rat is affected by protocatechuic acid. J. Nutr. Sci. Vitaminol. 2004, 50, 13-18.

232. Chung, M.J.; Sung, N.-J.; Park, C.-S.; Kweon, D.-K.; Mantovani, A.; Moon, T.-W.; Lee, S.-J.; Park, K.H. Antioxidative and hypocholesterolemic activities of water-soluble puerarin glycosides in HepG2 cells and in C57BL/6J mice. Eur. J. Pharmacol. 2008, 578, 159-170. [CrossRef]

233. Zhang, K.; Song, W.; Li, D.; Jin, X. Apigenin in the regulation of cholesterol metabolism and protection of blood vessels. Exp. Ther. Med. 2017, 13, 1719-1724. [CrossRef]

234. Wong, T.Y.; Tan, Y.Q.; Lin, S.-m.; Leung, L.K. Co-administrating apigenin in a high-cholesterol diet prevents hypercholesterolaemia in golden hamsters. J. Pharm. Pharmacol. 2018, 70, 1253-1261. [CrossRef]

235. Liu, G.; Zhang, Y.; Liu, C.; Xu, D.; Zhang, R.; Cheng, Y.; Pan, Y.; Huang, C.; Chen, Y. Luteolin Alleviates Alcoholic Liver Disease Induced by Chronic and Binge Ethanol Feeding in Mice. J. Nutr. 2014, 144, 1009-1015. [CrossRef]

236. Li, J.; Inoue, J.; Choi, J.-M.; Nakamura, S.; Yan, Z.; Fushinobu, S.; Kamada, H.; Kato, H.; Hashidume, T.; Shimizu, M.; et al. Identification of the Flavonoid Luteolin as a Repressor of the Transcription Factor Hepatocyte Nuclear Factor 4 alpha. J. Biol. Chem. 2015, 290, 24021-24035. [CrossRef]

237. Sa, C.; Oliveira, A.R.; Machado, C.; Azevedo, M.; Pereira-Wilson, C. Effects on Liver Lipid Metabolism of the Naturally Occurring Dietary Flavone Luteolin-7-glucoside. Evid. Based Complement. Altern. Med. 2015, 2015, 647832. [CrossRef]

238. Duwensee, K.; Schwaiger, S.; Tancevski, I.; Eller, K.; van Eck, M.; Markt, P.; Linder, T.; Stanzl, U.; Ritsch, A.; Patsch, J.R.; et al. Leoligin, the major lignan from Edelweiss, activates cholesteryl ester transfer protein. Atherosclerosis 2011, 219, 109-115. [CrossRef] 
239. Liang, Y.T.; Chen, J.; Jiao, R.; Peng, C.; Zuo, Y.; Lei, L.; Liu, Y.; Wang, X.; Ma, K.Y.; Huang, Y.; et al. Cholesterol-Lowering Activity of Sesamin Is Associated with Down-Regulation on Genes of Sterol Transporters Involved in Cholesterol Absorption. J. Agric. Food Chem. 2015, 63, 2963-2969. [CrossRef]

240. Fale, P.L.; Ferreira, C.; Maruzzella, F.; Florencio, M.H.; Frazao, F.N.; Serralheiro, M.L.M. Evaluation of cholesterol absorption and biosynthesis by decoctions of Annona cherimola leaves. J. Ethnopharmacol. 2013, 150, 718-723. [CrossRef]

241. Morin, B.; Nichols, L.A.; Zalasky, K.M.; Davis, J.W.; Manthey, J.A.; Holland, L.J. The citrus flavonoids hesperetin and nobiletin differentially regulate low density lipoprotein receptor gene transcription in HepG2 liver cells. J. Nutr. 2008, 138, 1274-1281. [CrossRef] [PubMed]

242. Miwa, Y.; Mitsuzumi, H.; Yamada, M.; Arai, N.; Tanabe, F.; Okada, K.; Kubota, M.; Chaen, H.; Sunayama, T.; Kibata, M. Suppression of apolipoprotein B secretion from HepG2 cells by glucosyl hesperidin. J. Nutr. Sci. Vitaminol. 2006, 52, $223-231$. [CrossRef] [PubMed] 